\title{
A ideologia do crescimento econômico e o discurso empresarial do desenvolvimento sustentável
}

\author{
LUIZ GuSTAVo ALVES DE LARA \\ Universidade Positivo / Programa de Mestrado e doutorado em AdMinistração, Curitiba - PR, Brasil \\ Universidade Estadual do CENTRO Oeste / Departamento de AdMINISTRAÇÃo, IRATI - PR, BRASIL \\ SAMIR AdAMOgLU de OliveIRA \\ Universidade Federal da Paraíba / Departamento de Administração, JoÃo Pessoa - PB, Brasil \\ Universidade Positivo / Programa de Mestrado e Doutorado em Administração, Curitiba - PR, Brasil \\ InStITUto BRAsileiro de ESTUdos E PESQUISAs SOCIAIS (IBEPES), CURITIBA - PR, BRASIL
}

\begin{abstract}
Resumo
Este estudo investiga a forma como a ideologia do crescimento lida com as contradições do discurso do desenvolvimento sustentável. Foram analisadas reportagens da mídia noticiosa que vinculavam empresas estatais e de economia mista do ramo de geração de energia elétrica listadas no Índice de Sustentabilidade Empresarial da Bolsa de Valores de São Paulo (ISE BM\&FBOVESPA) às dimensões do desenvolvimento sustentável do Triple Bottom Line (3BL). Também foram analisados seus relatórios de sustentabilidade. Os dados coletados são datados de 2005 a 2013. Às reportagens foi empregada análise de conteúdo, buscando evidências de acontecimentos noticiados que relacionam aquelas empresas ao tema desenvolvimento sustentável. Aos relatórios de sustentabilidade foi empregada análise de discurso, com a finalidade de identificar manifestações ideológicas no discurso da sustentabilidade. Os resultados foram discutidos dialeticamente, pautados na conceituação de 'ideologia' sugerida por Giddens (1979). Verificou-se que os componentes ideológicos do crescimento transferem-se para o discurso do desenvolvimento sustentável mediante eufemismos e deslizes semânticos, permitindo às empresas usufruir das propriedades polissêmicas da linguagem para ressignificá-la por meio da (i) reificação do presente; (ii) defesa do crescimento como algo de interesse primariamente coletivo; e (iii) negação das contradições, evidenciadas como conflitos entre as dimensões ambiental, econômica e social do modelo 3BL.
\end{abstract}

Palavras-chave: Crescimento econômico. Desenvolvimento sustentável. Discurso. Ideologia.

\section{The ideology of economic growth and the business discourse of sustainable development}

\begin{abstract}
This study investigates the way the growth ideology deals with the contradictions of sustainable development discourse. Reports from newspapers were analyzed, which linked state-owned companies and companies of mixed economy operating in the business of electricity generation and listed in the ISE BM\&FBOVESPA to the dimensions of sustainable development of the Triple Bottom Line (3BL). Also, the sustainability reports of those companies were analyzed. The data collected is dated from 2005 to 2013 . The media reports underwent content analysis aiming to find reported facts that linked those enterprises to the sustainable development themes. The reports of sustainability underwent discourse analysis with the purpose of identifying ideological demonstrations in the sustainability discourse. Using Giddens's (1979) conceptualization of 'ideology', the results indicated that the growth ideology components are transferred to the discourse of sustainable development through euphemisms and semantic slips. This allows companies to take advantage of the polysemous properties of language to re-signify them by (i) the reification of the present; (ii) the defense of growth as if it were of primary collective interest, and (iii) the denial of contradictions, evidenced by conflicts between the environmental, economic and social dimensions of the Triple Bottom Line concept.
\end{abstract}

Keywords: Economic Growth. Sustainable Development. Discourse. Ideology.

\section{La ideología del crecimiento económico y el discurso empresarial del desarrollo sostenible}

\section{Resumen}

Este estudio investiga cómo la ideología del crecimiento trata las contradicciones del discurso del desarrollo sostenible. Se analizaron reportajes de los medios de comunicación que vinculaban empresas estatales y de economía mixta del ramo de generación de energía eléctrica listadas en el Índice de Sostenibilidad Empresarial de la Bolsa de Valores de São Paulo (ISE BM\&FBOVESPA) a las dimensiones del desarrollo sostenible del Triple Bottom Line (3BL). También se analizaron sus informes de sostenibilidad. Los datos recogidos están fechados entre 2005 y 2013 . En los reportajes se aplicó el análisis de contenido, en busca de evidencia de eventos informados que relacionaran dichas empresas con el tema desarrollo sostenible. En los informes de sostenibilidad se aplicó el análisis de discurso, con el fin de identificar manifestaciones ideológicas en el discurso de la sostenibilidad. Los resultados se discutieron dialécticamente, guiados por el concepto de 'ideología' sugerido por Giddens (1979). Se constató que los componentes ideológicos del crecimiento se transfieren al discurso del desarrollo sostenible a través de eufemismos y deslices semánticos, lo que permite que las empresas se valgan de las propiedades polisémicas del lenguaje para darle un nuevo significado a través de (i) reificación del presente; (ii) defensa del crecimiento como algo de interés primordialmente colectivo; y (iii) negación de las contradicciones, evidenciadas como conflictos entre las dimensiones ambiental, económica y social del modelo 3BL.

Palabras clave: Crecimiento económico. Desarrollo sostenible. Discurso. Ideología.

Artigo submetido em 12 de fevereiro de 2016 e aceito para publicação em 29 de dezembro de 2016.

Os autores gostariam de agradecer aos avaliadores que apreciaram este texto ao longo do seu processo de avaliação às cegas, pelas diversas críticas e também sugestões de leituras que possibilitaram fortalecer e desenvolver o texto até sua versão final publicada. Os autores também agradecem aos professores Fabio Vizeu e Rene Eugênio Seifert pelo auxílio no desenvolvimento do estudo apresentado nesse artigo. Além de seus trabalhos terem provocado reflexões importantes que contribuíram para o referencial teórico desta pesquisa, suas apreciações críticas foram de grande valia para o refinamento de nossos argumentos.

DOI: http://dx.doi.org/10.1590/1679-395159387 


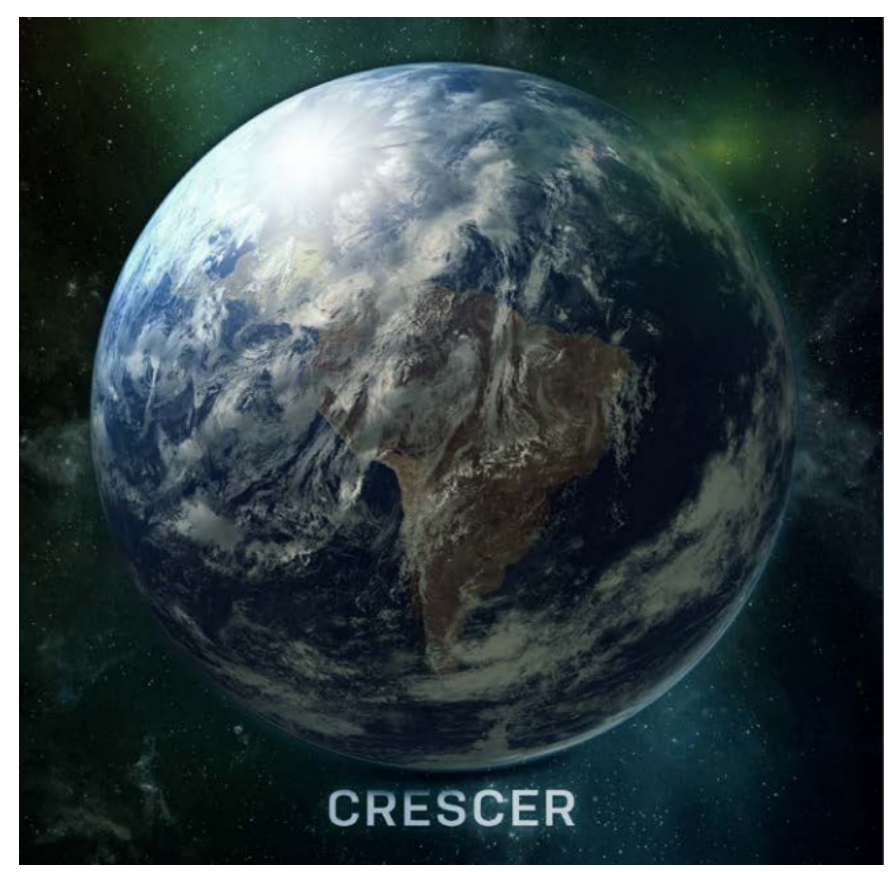

\section{INTRODUÇÃo}

Na modernidade, o desenvolvimento sustentável tornou-se o caminho inexorável rumo a uma sociedade ideal, ao passo que a consecução desse projeto tem sido indissociada da necessidade de crescimento econômico. No entanto, a concepção hegemônica de desenvolvimento sustentável traz consigo as contradições lógicas dos sistemas econômicos produtivistas causadores de desequilíbrio ambiental e social.

Os benefícios e os danos que o desenvolvimento baseado no crescimento econômico causa no âmbito social e no meio ambiente há décadas geram debates. Relatórios, conferências e congressos têm constituído palco de discussões controversas. Dentre os acontecimentos históricos que fomentaram o debate se destacam o relatório do Clube de Roma, de 1972, a Conferência sobre o Homem e o Meio Ambiente, ou Conferência de Estocolmo, também de 1972, o Relatório Brundtland, intitulado "Nosso Futuro Comum", de 1987, e a Conferência das Nações Unidas sobre o Meio Ambiente e Desenvolvimento, ou RIO-92, de 1992, e a Conferência das Nações Unidas sobre Desenvolvimento Natural, ou Rio+20, de 2012 (VIZEU, MENEGHETTI e SEIFERT, 2012).

Embora sejam muitos os conceitos de desenvolvimento sustentável propostos ao longo desses anos, o mais perene é o descrito no Relatório Brundtland, que o define como "aquele que atende as necessidades do presente, sem comprometer a possibilidade de as gerações futuras atenderem as suas próprias necessidades" (COMISSÃO DE BRUNDTLAND, 1991, p. 47). Em torno dessa definição, há uma vasta produção acadêmica sob olhares tanto funcionalistas quanto críticos.

Para Marconatto, Trevisan, Pedrozo et al. (2013), muitas dessas discussões têm sido polarizadas entre aqueles defendem a preservação da natureza como fim e outros que defendem sua utilização para garantia de desenvolvimento econômico. Há correntes de pensamentos que tentam viabilizar uma aproximação entre essas perspectivas extremadas; entretanto, algumas vêm recebendo críticas pela proposição de modelos que mantêm a lógica de necessidade de crescimento econômico ilimitado do capitalismo por meio do consumo de recursos planetários finitos (BANERJEE, 2003; CASTRO, 2004; FOLADORI, 2001; LATOUCHE, 2009; NORMAN e MACDONALD, 2004; VIZEU, MENEGHETTI E SEIFERT, 2012; WANNER, 2015).

\footnotetext{
* Fonte da imagem: Adaptado de Cemig (2012).
} 
A abordagem mais influente no mundo corporativo é o desenvolvimento sustentável idealizado por Elkington (1997); o autor apresenta uma nova orientação para o desenvolvimento, baseada não só nos interesses econômicos, mas também nas dimensões ambientais e sociais, em tríplice harmonia (NORMAN e MCDONALD, 2004). Essa ideia é a base dos relatórios de sustentabilidade emitidos pelas corporações. No entanto, a fragilidade desses relatórios torna-se patente, por ser compilados com informações seletivas para demonstrar cenários harmoniosos entre as três dimensões (NORMAN e MCDONALD, 2004). Para Banerjee (2003), o discurso da sustentabilidade e da responsabilidade social está cada vez mais presente nas corporações, mas com o objetivo de aumentar as oportunidades de maximização do lucro por meio dos problemas socioambientais causados pela própria lógica do livre mercado, na qual essas organizações estão inseridas.

Nesse contexto, buscamos compreender como o discurso do desenvolvimento sustentável coexiste e relaciona-se com efeitos colaterais sistêmicos da economia de mercado, tais como o crescente desequilíbrio ambiental e a assimetria da distribuição de riquezas. A pergunta condutora desta pesquisa foi: Como a ideologia do crescimento lida com as contradições do discurso do desenvolvimento sustentável? Optamos por investigar o tema por meio de empresas estatais e de economia mista do ramo de geração de energia listadas no Índice de Sustentabilidade Empresarial da Bolsa de Valores de São Paulo (ISE BM\&FBOVESPA). A escolha desse caso se deu em função da atividade de grande impacto socioambiental no entorno das instalações dessas empresas. Paradoxalmente, esse grupo de empresas compôs a carteira de ações de empresas referenciadas por suas práticas de sustentabilidade desde 2005, quando foi instituído o Índice de Sustentabilidade Empresarial no Brasil (ISE). A composição patrimonial caracterizada pelo controle governamental resulta em uma trama de interesses da esfera pública com a esfera privada que impacta as dimensões ambiental, social e econômica do país. Foram analisados conteúdos de reportagens que associavam essas empresas às dimensões do Triple Bottom Line (3BL) e, também, o discurso de seus relatórios de sustentabilidade emitidos entre 2005 e 2013.

Revisando as publicações nacionais, constatamos escassez de estudos que analisam o discurso das empresas do ISE BM\&FBOVESPA a partir de literatura crítica. Já em relação ao ramo de geração de energia, Silva, Reis e Amancio (2011) empreenderam uma análise de conteúdo dos relatórios de três organizações do setor, buscando compreender a relação entre os significados de sustentabilidade e os paradigmas ambientais, antropocêntricos e ecocêntricos que se manifestam nos debates. Este artigo, por sua vez, almeja contribuir com o avanço da reflexão crítica sobre o discurso do desenvolvimento sustentável no contexto brasileiro, por meio de um estudo instrumental de empresas do setor de geração de energia listadas no ISE BM\&FBOVESPA. Entendemos que a estratégia metodológica que combinou uma modalidade específica de análise de conteúdo de reportagens com a análise de discurso dos relatórios de sustentabilidade foi fundamental para uma discussão robusta sobre contradições do desenvolvimento sustentável. Assim, nossa principal contribuição com o campo consiste na exploração da materialidade da ideologia do crescimento econômico do contexto brasileiro presente nos relatórios de sustentabilidade desse grupo de empresas, contrastada com relatos de acontecimentos noticiados pela mídia jornalística, que as associam às dimensões do 3BL.

Iniciaremos com uma (i) revisão teórica, seguindo pelo (ii) percurso metodológico adotado, que foi subdividido entre seções de análise de conteúdo e análise de discurso, para, então, apresentarmos uma (iii) discussão dialética dos resultados, concluindo com nossas (iv) reflexões finais.

\section{REFERENCIAL TEÓRICO}

Apresentamos nesta sessão a revisão teórica do tema de pesquisa organizado em (i) breve revisão do conceito de desenvolvimento na modernidade, (ii) o conceito de desenvolvimento sustentável, (iii) o discurso corporativo do desenvolvimento sustentável e (iv) as relações entre linguagem, ideologia e discurso.

\section{BREVE REVISÃO DO CONCEITO DE DESENVOLVIMENTO NA MODERNIDADE}

O significado de 'desenvolvimento' na modernidade não está ontologicamente ligado à evolução da sociedade (BANERJEE, 2003; GÓMEZ, 2002). Foi após a Segunda Guerra Mundial que o desenvolvimento passou a fazer parte da agenda para 
construção da nova ordem internacional, sob grande influência dos Estados Unidos da América (EUA) (ILLICH, 2010). A partir do conceito antitético de subdesenvolvimento, foi convencionado que o desenvolvimento estava relacionado ao crescimento econômico ${ }^{1}$.

Naquele contexto histórico, os territórios coloniais que se tornavam independentes estavam em estado de extrema pobreza e os países industrializados precisavam ser reconstruídos, tendo em vista que sofreram danos estruturais na guerra (GÓMEZ, 2002). Apesar de ter sido usado por mais de dois séculos, o termo 'desenvolvimento' ganhou seu atual significado no discurso de posse do presidente dos EUA, Harry Truman, em 20 de janeiro de 1949 (BANERJEE, 2003). Na ocasião, o desenvolvimento foi definido a partir de sua antítese: pela primeira vez o termo 'subdesenvolvimento' foi utilizado, referindo-se a 2 bilhões de pessoas pertencentes ao chamado 'terceiro mundo', e que seriam liderados pelos EUA rumo ao crescimento econômico e industrial (ESTEVA, 2010, p. 6):

Usando a palavra "subdesenvolvido" pela primeira vez em tal contexto, Truman mudou o significado do desenvolvimento e criou o emblema, um eufemismo, usado desde então para aludir discreta ou inadvertidamente à era da hegemonia americana.

Para Gómez (2002), o plano desenvolvimentista pode ser dividido em três fases. A primeira teve início nos anos 1950 e focou o crescimento econômico, culminando em 1962, com a escolha do Produto Nacional Bruto (PNB) como referência para determinação de quais eram os países pobres e quais eram os países ricos (ESTEVA, 2010; GÓMES, 2002). Para Rattner (1974, p. 146), o crescimento econômico mensurado pelo PNB e pela renda per capita "foi elevado a um dos valores supremos da sociedade". A segunda fase foi o fracasso dessas métricas, algo notado entre 1960 e 1970 (GÓMEZ, 2002), quando se reconheceu que o crescimento do PNB não era capaz de reduzir a pobreza (RATTNER, 1974; SCHUMACHER, 1983), iniciando um movimento para identificar aspectos qualitativos da produção alheios àquele índice que fossem capazes de melhorar as condições de vida dos países subdesenvolvidos:

Enquanto a primeira década considerava separadamente os aspectos sociais e econômicos do desenvolvimento, a segunda década envolveu a fusão dos dois. Um novo paradigma teve que ser formulado, o da integração, depois de reconhecer a necessária interação de recursos físicos, processos técnicos, aspectos econômicos e mudança social. A Estratégia de Desenvolvimento Internacional, proclamada em 24 de outubro de 1970, apelou a uma estratégia global, baseada em ações conjuntas e concentradas em todas as esferas da vida econômica e social (ESTEVA, 2010, p. 10).

A terceira fase, emergida em meados da década de 1980, foi marcada pela necessidade de atingir o desenvolvimento com a utilização não predatória dos recursos naturais, enquanto condição de sustentação do capital. Um dos principais marcos desse período foi a divulgação do relatório da Comissão Mundial sobre Meio Ambiente e Desenvolvimento, intitulado "Nosso Futuro Comum", também conhecido como Relatório Brundtland (COMISSÃO DE BRUNDTLAND, 1991). Nesse relatório foi consolidada a definição amplamente aceita de desenvolvimento sustentável (MEADOWS, RANDERS e MEADOWS, 2007; VIZEU, MENEGHETTI e SEIFERT, 2012).

\section{O CONCEITO DE DESENVOLVIMENTO SUSTENTÁVEL}

O desenvolvimento idealizado sob bases puramente econômicas mostrou-se falho já na década que sucedeu o discurso do presidente Truman. No mesmo contexto histórico, entre 1960 e 1970, propagavam-se protestos contra políticas do governo dos EUA e a utilização de agentes químicos na Guerra do Vietnã, ainda ressoando as vozes do movimento hippie em fóruns (FOLADORI, 2001; VIZEU, MENEGHETTI e SEIFERT, 2012). Os movimentos ambientalistas tomaram a forma de organizações como Greenpeace, Verdes da Alemanha, Earth First (Amigos da Terra), entre outros (FOLADORI, 2001).

\footnotetext{
${ }^{1}$ Segundo Matitz e Vizeu (2012, p. 583), as definições terminológicas "estão diretamente relacionadas ao significado de termos ou expressões no contexto de uma determinada ciência", delimitando fronteiras de significação em torno das categorias e dos elementos teorizados em seus contextos históricos específicos.
} 
Um dos fatos mais relevantes na ascensão do debate sobre a relação entre homem e a natureza ocorreu em 1972 - mesmo ano da Conferência de Estocolmo. Publicou-se um estudo feito sob encomenda pelo Clube de Roma, que alertava para os potenciais "Limites do crescimento", título do livro que causou enorme impacto ao alertar que, se não fossem alterados os ritmos de produção e da extração de recursos, o mundo se depararia com o caos social e ambiental (FOLADORI, 2001; MEADOWS, RANDERS e MEADOWS, 2007; VIZEU, MENEGHETTI e SEIFERT, 2012).

A partir desse confronto de ideias surgiram conceitos e propostas para a promoção de um desenvolvimento conciliador de interesses axiologicamente distantes. Em 1987, no Relatório Brundtland (COMISSÃO DE BRUNDTLAND, 1991), 'desenvolvimento' é apresentado com um novo qualificador: 'sustentável'. Isso representou um novo modelo conceitual harmônico e virtuoso que integraria a agenda de desenvolvimento das nações, de modo que esse relatório apresentou uma definição duradoura de desenvolvimento sustentável: "aquele que atende as necessidades do presente, sem comprometer a possibilidade de as gerações futuras atenderem as suas próprias necessidades" (COMISSÃO DE BRUNDTLAND, 1991, p. 47). Ao longo dos anos que se seguiram a essa publicação, a discussão sobre sustentabilidade foi conduzida por meio de duas visões antagônicas: antropocentristas e ecocentristas (MARCONATTO, TREVISAN, PEDROZO et al., 2013; SILVA, REIS e AMANCIO, 2011).

Na visão antropocentrista, admite-se que a natureza deva ser explorada pelo ser humano, essa é uma ação legítima, dada sua relação de superioridade em relação aos demais seres vivos. A consciência da própria existência torna o homem capaz de administrar os recursos naturais disponíveis e tenta, por meio deles, gerar riqueza capaz de desenvolver tecnologias mais eficientes e menos degradantes. $\mathrm{O}$ avanço econômico nessa visão representa o progresso tecnológico que irá garantir a utilização otimizada dos recursos disponíveis e permitirá recuperar os danos socioambientais já causados, até se alcançar o desenvolvimento sustentável (MARCONATTO, TREVISAN, PEDROZO et al., 2013). Essa visão antropocêntrica do mundo é um paradigma social hegemônico.

Em contraponto, os ecocentristas consideram o meio ambiente tão importante quanto o ser humano e não admitem a exploração predatória de recursos naturais em função dos desejos da sociedade capitalista. A partir desse ponto de vista, a pegada ecológica ${ }^{2}$ deixada pelo desenvolvimento econômico capitalista não é justificada pela tentativa de desenvolvimento de tecnologias que sejam capazes de apagá-las (MARCONATTO, TREVISAN, PEDROZO et al., 2013; SILVA, REIS e AMANCIO, 2011).

Durante a década de 1990, popularizou-se o modelo 3BL, que busca mensurar e equilibrar quantitativamente os impactos econômicos, sociais e ambientais das organizações (BANERJEE, 2003; NORMAN e MACDONALD, 2004).

Em resumo, o 3BL defende a crença de que o desempenho social (e ambiental) pode ser medido de maneira objetiva e que as empresas devem usar esses resultados para melhorar seu desempenho social (e ambiental). Além disso, elas devem relatar esses resultados por uma questão de princípio, e ao usar e relatar esses pilares adicionais que formam o tripé da sustentabilidade, as empresas esperam poder melhorar seus resultados financeiros a longo prazo (NORMAN e MACDONALD, 2004, p. 246).

O discurso dominante da sustentabilidade tem forte influência do 3BL por promover a conciliação entre extremos que defendem causas sociais, ambientais e econômicas. Em termos práticos, seria promover o crescimento econômico de forma conjunta com o desenvolvimento de índices sociais e em harmonia com o meio ambiente (ELKINGTON, 1997).

No contexto pré-Rio+20, algumas grandes potências econômicas estavam desenvolvendo estratégias para o desenvolvimento sustentável ao redor do mundo. Entretanto, para Wanner (2015), mesmo que países como Japão, Alemanha, Coreia do Sul e China tenham empurrado o crescimento econômico para um novo paradigma econômico, sob o conceito de economia verde, eles ainda são profundamente enraizados no capitalismo neoliberal. Apesar desse movimento ter conseguido colocar a questão do meio ambiente na agenda do desenvolvimento das nações, pouco se obteve em resultados concretos (VIZEU, MENEGHETTI e SEIFERT, 2012).

Wanner (2015) lembra que, na abordagem econômica neoliberal do desenvolvimento sustentável, existe a crença de que os recursos naturais poderão ser substituídos por outras formas de capital, em caso de esgotamento. Para Marconatto, Trevisan, Pedrozo et al. (2013), abordagens como a ecologia industrial e a teoria dos stakeholders representam uma importante

\footnotetext{
${ }^{2}$ Danos ambientais decorrentes dos modos de produção de consumo.
} 
possibilidade de conciliação de interesses entre industriais e ambientalistas. Entretanto, segundo Latouche (2009), a crença na possibilidade de poder substituir recursos naturais por mecanismos artificiais possibilita à economia capitalista dar resposta a qualquer questionamento quanto à sustentabilidade do modelo de produção. Seifert e Vizeu (2015b, p. 163) afirmam que "a crença no crescimento sem limites se sustenta na esperança de que os feitos científicos e tecnológicos permitirão que o modo de administrar centrado no crescimento possa permanecer o mesmo".

\section{O DISCURSO CORPORATIVO DO DESENVOLVIMENTO SUSTENTÁVEL}

Durante as últimas décadas, cresceu o número de publicações alertando para a incapacidade ambiental de suportar a busca por crescimento (MEADOWS, RANDERS e MEADOWS, 2007). No entanto, o capital se apropriou das críticas para apresentar soluções dentro de sua própria lógica de acumulação (WANNER, 2015). Isso garantiu a manutenção dos interesses da economia de mercado em consonância com as aspirações por modelos de produção que diminuíssem o dano ambiental de nosso modo de vida, mas que, na realidade, jamais se concretizaram (LATOUCHE, 2009).

Como tentativa de resposta a esses problemas, nas últimas décadas, as empresas passaram a afirmar compromissos éticos e socioambientais. Banerjee (2008) aponta três premissas por trás do discurso de responsabilidade social corporativa (RSC): (i) além de acumular dinheiro, as empresas devem estar atentas às questões sociais e ambientais; (ii) devem demonstrar o mais alto nível de transparência e integridade; e (iii) as empresas devem estar comprometidas com o bem-estar social da comunidade. Nessa lógica, as empresas socialmente responsáveis têm maior retorno financeiro, e aquelas que não demonstram tais preocupações seriam naturalmente banidas pela lógica de mercado. No entanto, o autor aponta a necessidade de maior criticidade ao analisar essa literatura:

É interessante observar como as noções de sustentabilidade são construídas, manipuladas e representadas tanto na imprensa de negócios quanto na literatura acadêmica. Como evidência dos efeitos deletérios do desenvolvimento, o discurso muda de desenvolvimento sustentável para uma visão mais positiva da sustentabilidade e, em seguida, desloca o foco para a sustentabilidade corporativa. Discursos corporativos sobre sustentabilidade produzem uma elisão que desloca o foco da sustentabilidade planetária global para sustentar a corporação através de "oportunidades de crescimento" (BANERJEE, 2003, p. 66).

As corporações utilizam o tema para geração de oportunidades em meio a crises socioambientais, assim, buscam garantir a manutenção do crescimento. Investidores do mercado de capitais, por exemplo, passaram a investir em empresas que discursam a sustentabilidade ou RSC, alavancando ganhos e mitigando riscos financeiros causados pela imagem contraproducente das corporações poluidoras e o impacto social negativo oriundo de tais imagens.

No final da década de 1980, surgiram fundos de investimentos denominados socialmente responsáveis - socially responsible investments (SRI) - que, segundo Marcondes (2010), apresentavam-se em plena expansão no período. Esses fundos afirmavam primar pela composição com ações de empresas cuja atividade causaria menor pegada ecológica e setores tecnológicos promissores, tais como a geração de energia limpa (MARCONDES, 2010). O discurso de responsabilidade social empresarial (RSE) em bolsas de valores ganhou espaço nas economias dos países dominantes tão logo se prometeu lucratividade com fundos SRI. Tal estratégia implica a tentativa de obter maior rentabilidade, uma vez que se reduzem os custos financeiros referentes a indenizações e compensações de impactos socioambientais quando as empresas são condenadas pela Justiça. É paradoxal, senão contraditório, que empresas de tabaco, fabricantes de armas e ramos de negócios poluidores divulguem relatórios demonstrando/afirmando estar totalmente alinhados com as premissas do 3BL (BANERJEE, 2003).

As atuais correntes dominantes do discurso da sustentabilidade estão carregadas de racionalidade econômica (BANERJEE, 2003). As regulamentações monopolizadas por agentes poucos politizados apontam um futuro em que as políticas ambientais serão determinadas pelos interesses do mercado, algo que, na percepção de Banerjee (2003), é incapaz de substituir o papel dos governos no que se refere a questões ambientais. É notável que o discurso da sustentabilidade é cada vez mais dominado pelos interesses corporativos. Em 1999, a bolsa de valores mais importante do mercado de capitais, a Dow Jones, lançou carteiras de investimentos mensurados por um índice de sustentabilidade, o Dow Jones Sustainability Indexes (DJSI), cujos princípios se 
baseiam na abordagem do 3BL. Naquela ocasião, o desenvolvimento sustentável foi discursado como aquele que visa a aumentar o valor do acionista de longo prazo, integrando as oportunidades de crescimento econômicos, ambientais e sociais em suas estratégias corporativas e de negócios (BANERJEE, 2008). A iniciativa foi tão assertiva do ponto de vista de desempenho da carteira que, em 2001, nos mesmos moldes, foi lançado o FTSE4Good, índice de sustentabilidade da Bolsa de Valores de Londres que, em seguida, influenciou a construção de um índice semelhante em Joanesburgo (MARCONDES, 2010).

Esse movimento global em busca de investimentos potenciais de baixo impacto ambiental - em voga com a reprodução do discurso da sustentabilidade nos moldes do 3BL, para o contexto do mercado de capitais - influenciou a criação do ISE lançado em 2005, cujas empresas mais bem avaliadas compõem uma carteira de investimentos da BM\&FBOVESPA (MARCONDES, 2010).

\section{AS RELAÇÕES ENTRE LINGUAGEM, IDEOLOGIA E DISCURSO}

O desenvolvimento sustentável é uma produção discursiva e histórica. Segundo Escobar (1995), sua genealogia situa-se na economia clássica que se consolidou a partir do século XVIII. Considerar o desenvolvimento enquanto um produto linguístico, histórico e cultural implica compreender como o desenvolvimento sustentável tornou-se um imperativo moderno. A seguir, argumentamos o caráter ideológico da linguagem e as produções discursivas que suportam a ordem social historicamente construída.

A linguagem é um fenômeno complexo, pois ao mesmo tempo pode ter aspectos individuais e sociais, sendo também física, fisiológica e psíquica (FIORIN, 1995). Nesse arcabouço teórico, evidencia-se que a língua não é transparente, que a história possui sua materialidade e que, embora feita pelo homem, ela também não lhe é transparente (ORLANDI, 2013). Tampouco o indivíduo é transparente para si e, assim, "a consciência adquire forma e existência nos signos criados por um grupo organizado no curso de suas relações sociais" (BAKHTIN, 2006, p. 34).

Por meio de linguagem, criam-se imagens de mundo; no entanto, essas imagens são condicionadas pelo contexto de cada época. Para Escobar (1995), o ordenamento social instituído pela economia é produto linguístico, cultural e histórico. Esse ordenamento social sob base econômica foi desenvolvido sob o argumento da neutralidade da ciência positivista, o que empoderou a economia com a verdade e submeteu a ordem social à sua linguagem (ESCOBAR, 1995). Habermas (1987, p. 21) afirma que a linguagem é ideológica por natureza e, por essa característica, pode ser sistematicamente significada com propósitos de ordenamento social:

Na medida em que as legitimações não manifestam a relação de violência, cuja institucionalização possibilitam, e na medida em que isso apenas se exprime nas legitimações, a linguagem também é ideológica. Aí não se trata apenas de enganos numa linguagem, mas sim de engano com a própria linguagem.

Considera-se que a ideologia se materializa na linguagem, tornando-se parte de seu funcionamento, imaginário e materializante articulado ao inconsciente (ORLANDI, 2013). As formações discursivas, por sua vez, "são a projeção, na linguagem, das formações ideológicas" (ORLANDI, 2010, p. 17). A partir de uma ideologia já constituída no processo de produção da realidade social, criam-se condições para a formação discursiva, determinando o que pode e deve ser dito (ORLANDI, 2013). 0 significado das palavras não é determinado pelo texto isoladamente, mas pela ideologia que nele se materializa e que lhe proporciona (con)textualidade (ORLANDI, 2013).

A ideologia materializada no discurso de posse do presidente Truman, que deu sentido à categorização entre países desenvolvidos e subdesenvolvidos, revelou uma imagem de mundo ordenado por critérios institucionalizados pela ciência econômica. Para Escobar (1995), a existência desses domínios naturalizados como pré-sociais devem ser criticados. O autor afirma que é possível desconstruir o discurso desenvolvimentista a partir da compreensão da raiz da economia ocidental, cujos pressupostos raramente são questionados, tomados como formas normais e naturais de como as coisas são.

Revisitando os conceitos de ideologia elaborados por Marx, Althusser, Habermas e Mannheim, Giddens (1979) desenvolveu três critérios que possibilitam identificar uma ideologia: (i) a representação de interesses privados como universais; (ii) a negação ou transmutação das contradições; e (iii) a naturalização do presente. A primeira dimensão da ideologia para Giddens (1979) se refere à representação de interesses privados como universais. Nota-se consonância com a concepção marxista no que diz respeito ao fato de que as ideias dominantes são determinadas pela classe dominante dessa época: 
O contexto primordial para a crítica da ideologia na política moderna da sociedade capitalista continua sendo a análise da dominação de classe. As lutas ideológicas mais importantes ainda recorrem à ocultação versus divulgação da dominação de classe como origem do processo de acumulação de capital (GIDDENS, 1979, p. 193).

A segunda dimensão proposta por Giddens (1979) diz respeito à negação ou a transmutação das contradições. Para o autor, é de interesse das classes dominantes que a existência de contradições às condições estruturais de suas ações seja negada e que a realidade seja acobertada para garantia da manutenção de privilégios. A terceira dimensão proposta na caracterização de um pensamento ideológico é a naturalização do presente, onde os grupos têm interesse na manutenção do status quo e, consequentemente, de seu poder de ação estrutural. Na medida em que ganham o caráter imutável de leis naturais, as relações sociais tendem a se reificar (GIDDENS, 1979).

Por meio desses critérios, Seifert e Vizeu (2015a) caracterizaram a orientação para o crescimento ilimitado como uma ideologia. Essa orientação é manifestada na literatura econômica e do management, onde o crescimento ${ }^{3}$ é sinônimo de aumento de rentabilidade, lucro e liquidez, ignorando os limites sociais e ambientais. E é essa orientação que nos autoriza investigar o discurso da sustentabilidade em sua acepção ideológica.

\section{PERCURSO METODOLÓGICO}

Para compreender como a ideologia do crescimento lida com as contradições do discurso do desenvolvimento sustentável, desenvolvemos uma pesquisa de natureza exploratória, seguindo abordagem qualitativa, exclusivamente pautado por dados secundários (BRYMAN e BELL, 2004). Enquanto estratégia de investigação, adotou-se um estudo instrumental com seis casos - portanto, multicaso, segundo Bryman e Bell (2004). As categorias analíticas pré-definidas para o início da investigação foram 'ideologia do crescimento' e 'discurso do desenvolvimento sustentável'.

O recorte temporal da pesquisa foi de ordem longitudinal (CORBETTA, 2003), cobrindo desde o ano de 2005 (ano da criação do ISE BM\&FBOVESPA) até o ano de 2013, ano-base dos relatórios que foram divulgados em 2014, momento em foi realizada a coleta de dados desta pesquisa. Entre as empresas listadas no ISE BM\&FBOVESPA, encontramos as do segmento de geração de energia elétrica, competitivas do ponto de vista do mercado, atuando em um ramo cujas instalações físicas promovem grandes impactos ambientais, econômicos e sociais. Salientamos, ainda, que as estatais de geração de energia foram as que apresentaram maior constância naquela carteira de investimentos. Dessa forma, definiu-se que o estudo seria realizado com as empresas brasileiras de economia mista do setor de geração de energia elétrica destacadas por suas práticas sustentáveis no ramo de atuação, que atendessem ao critério de permanência na carteira ISE BM\&FBOVESPA, ao longo da janela temporal assumida. Assim, foram selecionadas 5 empresas: (i) Centrais Elétricas de Santa Catarina S.A. (Celesc); (ii) Companhia Elétrica de São Paulo (Cesp); (iii) Companhia Energética de Minas Gerais S.A. (Cemig); (iv) Companhia Paranaense de Energia S.A. (Copel); e (v) Centrais Elétricas Brasileiras S.A. (Eletrobras).

Para a investigação do fenômeno, optamos por formar dois corpus analisados com dois métodos distintos. O primeiro se trata de uma análise de conteúdo de reportagens veiculadas pela mídia jornalística buscando fatos que associavam as dimensões do $3 B \mathrm{~B}$ às empresas selecionadas para o estudo. O segundo se trata da análise de discurso de relatórios de sustentabilidade produzidos pelas próprias organizações estudadas, nos quais são apresentadas as concepções e as iniciativas na consecução do desenvolvimento sustentável, em seu âmbito corporativo. Por meio da análise de discurso, buscamos compreender como as dimensões do 3BL são significadas. Após a apresentação das duas análises, os resultados serão discutidos em uma única seção, confrontando os relatos de acontecimentos veiculados pela mídia jornalística com as significações construídas pelo discurso nos relatórios de sustentabilidade.

A seguir, detalhamos como foi formado o corpus da análise de conteúdo e, na sequência, os dispositivos constituídos para a análise de discurso.

\footnotetext{
${ }^{3}$ Deste ponto em diante, 'crescimento' será mencionado referindo-se ao seu significante determinado pela racionalidade dos sistemas econômicos que se baseiam na necessidade de crescimento ilimitado de produção e consumo para não colapsar.
} 


\section{PROCEDIMENTOS PARA A FORMAÇÃo DO CORPUS DA ANÁLISE DE CONTEÚDO}

Na formação deste corpus foram utilizados documentos que pudessem revelar alguma facticidade das práticas e dos impactos econômicos, sociais e ambientais daquelas empresas. Eles foram coletados a partir de reportagens de jornais de grande circulação presentes nas regiões geográficas onde as sedes das empresas se localizavam. Tais reportagens foram tomadas e entendidas como a materialização de acontecimentos compreendendo que, mesmo com limitações resultantes da intencionalidade de produção de sentido de emissor para receptor (algo próprio à mídia noticiosa), em maior ou menor grau, guardavam fidelidade a acontecimentos úteis na comparação com o discurso dos relatórios.

As etapas de (i) pré-análise, (ii) exploração, (iii) análise do material e (iv) interpretação dos dados da análise de conteúdo sugeridos por Bardin (2010) foram apropriados e adaptados, de modo a auxiliar na etapa de categorização do que viria a compor o corpus a ser analisado. Apresentamos nesta seção os procedimentos de (i) pré-análise, que consiste na sistematização das ideias que viabilizam a formação de um corpus. Foi estabelecido um protocolo prévio para escolha dos jornais dos quais seriam extraídos os dados. Os critérios de escolha foram concebidos conforme as necessidades determinantes para viabilização do estudo, e ordenados da seguinte forma:

1. Disponibilização de edições digitalizadas a partir de 2005;

2. Disponibilidade de mecanismos de busca que viabilizassem a busca por palavras-chave;

3. Escolha do jornal de maior circulação que atendesse aos critérios anteriores para cada estado onde as empresas estão sediadas.

Atenderam aos critérios os jornais: O Globo (Rio de janeiro, estado sede da Eletrobras); O Estado de S. Paulo (Estadão) (São Paulo, estado sede da Cesp); e Gazeta do Povo (Paraná, estado sede da Copel). Foram realizadas buscas com as palavras-chave provenientes das dimensões do 3BL4 , utilizadas como categorias temáticas da análise de conteúdo. Nessa etapa, foram identificadas 209 matérias jornalísticas associadas às empresas selecionadas que continham os termos 'sustentabilidade ambiental' e/ou 'sustentabilidade social' e/ou 'sustentabilidade econômica'. A Figura 1 ilustra, em diagrama de fluxo, as etapas desse procedimento.

Figura 1

\section{Formação do corpus da análise de conteúdo}

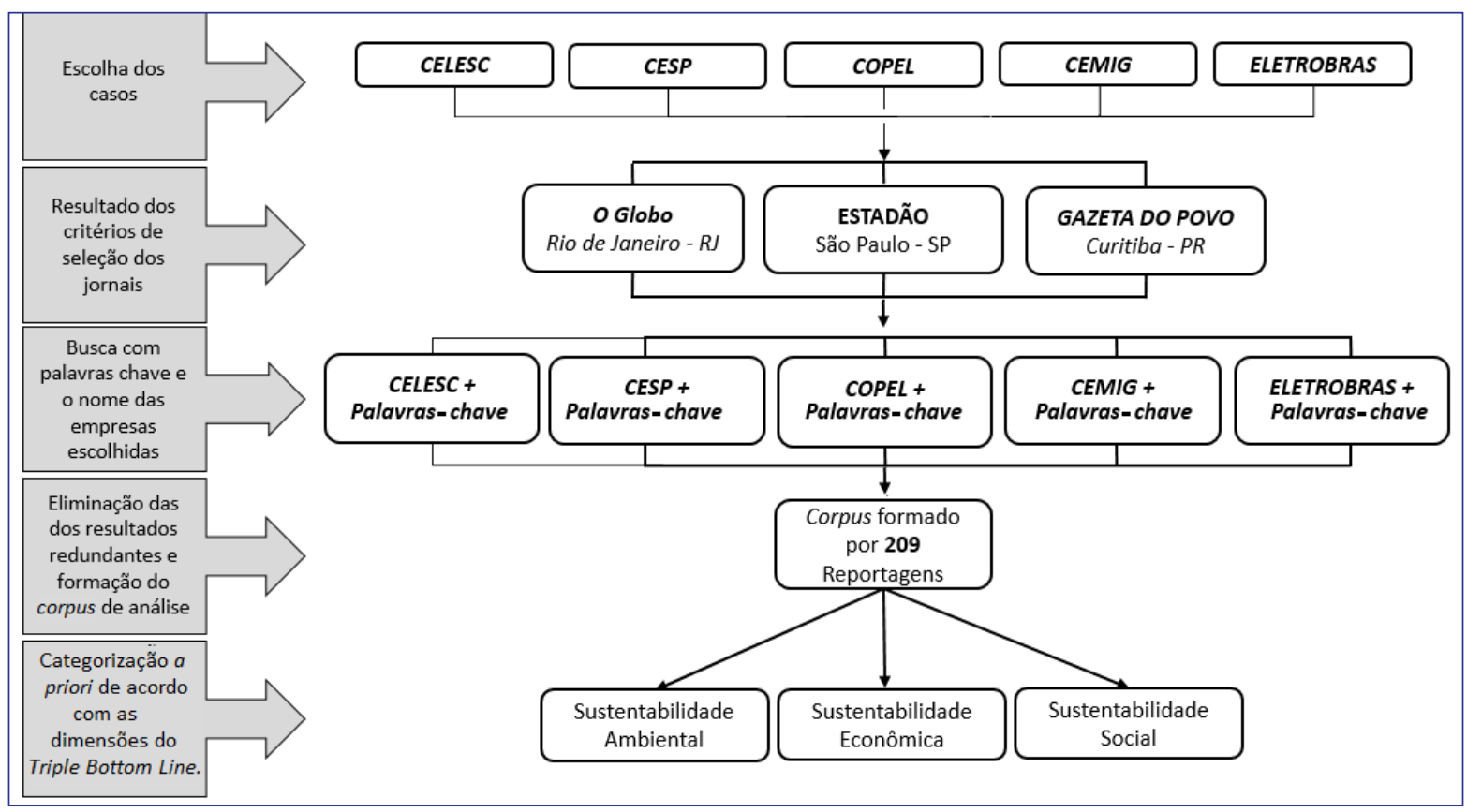

Fonte: Elaborada pelos autores.

\footnotetext{
${ }^{4}$ Optou-se pela busca com a palavra sustentabilidade em combinação com as dimensões do 3BL, assumindo-as como categorias temáticas a priori da análise de conteúdo. Esse sequenciamento de busca foi elaborado seguindo a própria estrutura temática dos relatórios de sustentabilidade para os quais foi empreendida análise de discurso. Tal simetria de categorias proporcionou ganhos analíticos, dada a sistematização para comparações temáticas semelhantes.
} 


\section{CONSTRUÇÃO DOS DISPOSITIVOS PARA A ANÁLISE DE DISCURSO}

Os procedimentos de análise de discurso foram baseados no método proposto por Orlandi (2013), que aponta a necessidade de dois dispositivos de análise: (i) teórico e (ii) analítico. O dispositivo teórico se constitui pelos conceitos e princípios da análise de discurso. A partir do dispositivo teórico, torna-se possível o delineamento do dispositivo analítico corpus de análise.

O que se espera do dispositivo do analista é que ele lhe permita trabalhar não em uma posição neutra, mas que seja relativizada em face da interpretação: é preciso que ele atravesse o efeito de transparência da linguagem, da literalidade do sentido e da onipotência do sujeito. Esse dispositivo vai assim investir na opacidade da linguagem, no descentramento do sujeito e no efeito metafórico, isto é, no equívoco, na falha e na materialidade. No trabalho da ideologia (ORLANDI, 2013, p. 61).

A seguir, detalha-se a constituição dos dispositivos de análise que ampararam este estudo.

\section{Dispositivo teórico}

Presumimos que a realidade é materializada pela linguagem, que a consciência do real é construída historicamente (HABERMAS, 1987; RICOEUR, 1990; ORLANDI, 2010), que a linguagem não é clara a quem lhe faz uso (ORLANDI, 2013) e carrega consigo a ideologia dominante que ordena a sociedade (HABERMAS, 1987). Por se relacionar com a linguagem, a ideologia torna-se um fenômeno social intransponível (RICOEUR, 1990). Assim, os processos de comunicação estão sujeitos a distorção sistemática, com vistas à manutenção do status quo e da dominação social (HABERMAS, 1987).

Os sentidos do real são produzidos ideologicamente e tudo que dizemos tem, pois, um traço ideológico em relação a outros traços ideológicos (ORLANDI, 2013). A partir de uma ideologia já constituída no processo de produção da realidade social, criam-se condições para a formação discursiva, determinando o que pode e deve ser dito (ORLANDI, 2013). Dessa forma, cada dimensão do tripé do 3BL se relaciona com os próprios relatórios e com sua exterioridade e são sustentadas por interdiscursos. O discurso do desenvolvimento sustentável não é, então, algo acabado, mas continua ressignificando signos determinados por correntes ideológicas. Assim, o discurso do desenvolvimento sustentável ganha materialidade em seu contexto sócio-histórico.

\section{Dispositivo analítico}

A escolha da análise de discurso teve por propósito compreender a influência da ideologia do crescimento no discurso do desenvolvimento sustentável. O corpus da análise foi composto por 33 relatórios de sustentabilidade das empresas selecionadas $^{5}$, cuja dimensão dos textos variou entre 68 e 227 páginas por relatório, totalizando 3.700 páginas mais 3 relatórios on-line com menus interativos - o que impossibilitou a determinação exata de sua extensão. Foram selecionados documentos referentes aos respectivos anos-base de divulgação dos relatórios em que as empresas selecionadas compuseram a carteira do ISE BM\&FBOVESPA. A localização dos documentos foi realizada por meio de sites de busca de conteúdo disponibilizados na Web 2.0 e nos sites institucionais das próprias empresas.

\section{ANÁLISES E RESULTADOS}

A seguir, apresentamos as análises de conteúdo das reportagens e do discurso dos relatórios de sustentabilidade, respectivamente.

\footnotetext{
${ }^{5} \mathrm{~A}$ escolha desses relatórios corresponde a todos os anos em que essas empresas foram listadas no ISE BM\&FBOVESPA. Detalhamos a quantidade de relatórios por empresa: 3 da Celesc; 9 da Cemig; 6 da Cesp (não foram obtidos os relatórios referentes a 2005 e 2007); 8 da Copel; e 6 da Eletrobras.
} 


\section{Análise de conteúdo}

Apresentamos nesta seção os resultados das etapas (ii) exploração, (iii) análise do material e (iv) interpretação dos dados, seguindo o método proposto por Bardin (2010), configurando os procedimentos adotados a posteriori à formação do corpus. $\mathrm{Na}$ fase (ii) exploração do material, notou-se que uma parcela expressiva de reportagens relatava conflitos e outra parcela veiculava informações que reforçavam a lógica dominante de necessidade de crescimento, apresentando suas vantagens para o desenvolvimento sustentável. Diante disso, a posteriori, conforme possibilidade prevista por Bardin (2010), foram elaboradas duas macrocategorias para a análise:

- Evidenciação de conflitos: nesta categoria foram alocadas as matérias cuja argumentação central evidenciava conflitos de interesses entre a busca do crescimento e a conciliação com a sustentabilidade ambiental, econômica e social, bem como os conflitos de governança corporativa.

- Visão desenvolvimentista: nesta categoria foram alocadas as matérias cuja argumentação central evidenciava a conciliação entre o crescimento e a sustentabilidade, nas dimensões do 3BL.

Procedendo à etapa (iii) análise do material, já foi possível notar um relativo equilíbrio entre as reportagens que evidenciavam conflitos (correspondendo a 49\%) e as que retratavam a visão desenvolvimentista predominante em seu conteúdo (correspondendo a 51\%). A sistematização dos procedimentos de categorização a priori e subcategorização com as dimensões do 3BL feitas a posteriori é apresentada na Figura 2.

Figura 2

Sistematização de categorias e subcategorias da análise

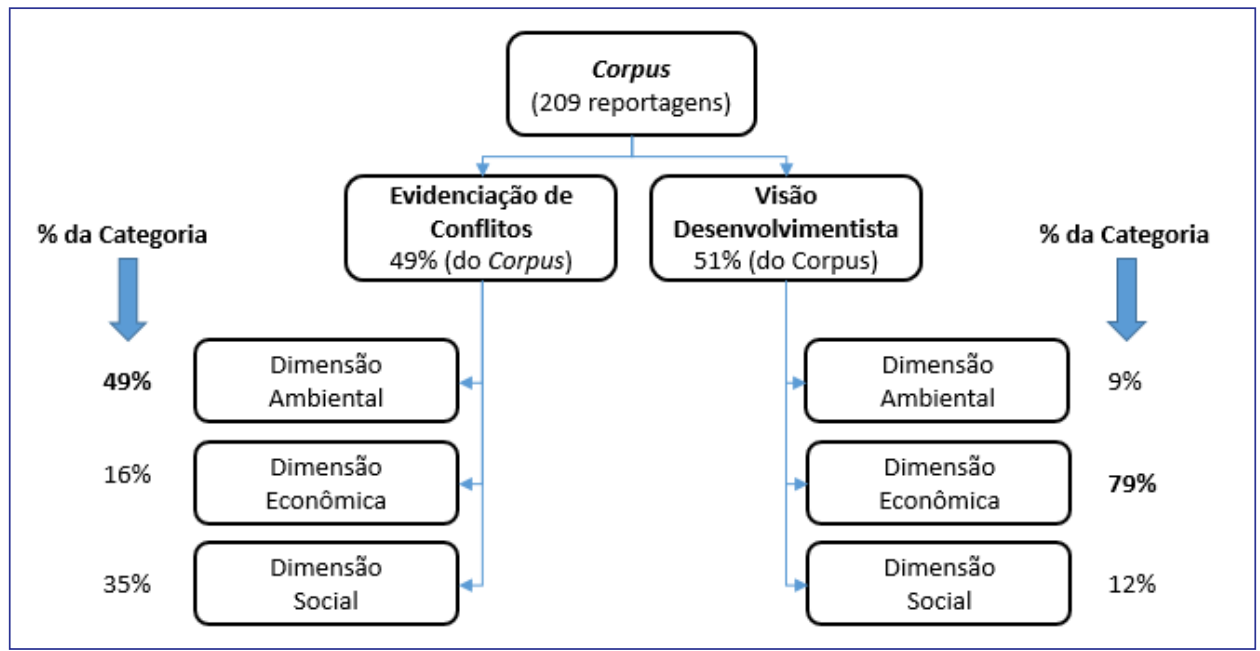

Fonte: Elaborada pelos autores.

Prosseguiu-se, então, com a etapa (iv) interpretação dos dados da análise de conteúdo, detalhada a seguir.

\section{VISÃO DESENVOLVIMENTISTA}

A dimensão econômica foi predominante na categoria 'visão desenvolvimentista', totalizando $79 \%$. As matérias, em sua maioria, baseavam-se em índices econômicos e descreviam uma preocupação uníssona do Estado refletida nas empresas selecionadas para nosso estudo multicaso, a saber: como garantir o crescimento? Apesar dos impactos tidos como indesejáveis, a construção de novas usinas é justificada pela necessidade de impulsionar o crescimento. Notou-se que, no Brasil, a principal estratégia de desenvolvimento dentro do período analisado foi o Programa de Aceleração de Crescimento (PAC) ${ }^{6}$, e que esta

${ }^{6}$ O Programa de Aceleração do Crescimento (PAC) foi o plano estratégico do Governo Federal para alavancar investimentos em setores estruturantes do país, visando ao crescimento econômico em 2007 (BRASIL, 2015). 
determinou o rumo das empresas do ramo de geração e distribuição de energia elétrica na busca por financiamentos e construção de novas usinas. Seguem alguns trechos de reportagens que representam essa categoria:

Haverá energia para crescer? A polêmica foi animada neste fim de semana, pelo Ministério da Fazenda, com o estudo mostrando os riscos de não haver energia suficiente para atender a um crescimento cada vez mais acelerado (LEITÃO, 2007, p. 20).

O Programa de aceleração do Crescimento (PAC) prevê o acréscimo de 12.386 megawatts à capacidade geradora até 2010. Mas, como observou o presidente do Acende Brasil, Claudio Sales, no PAC há mais obras previstas, e que devem ser aceleradas, do que investimentos novos. [...] Para atender às necessidades do País, seriam necessários investimentos anuais de cerca de US\$ 7,5 bilhões, ou pouco mais de $\mathrm{R} \$ 15$ bilhões, de acordo com o estudo do Acende Brasil. Algumas empresas calculam investimentos maiores, de até R\$ 20 bilhões por ano (O ESTADO DE S. PAULO, 23 abr. 2007, p. 3).

Para garantir o atendimento ao consumo de energia elétrica no país, a Eletrobras e suas principais subsidiárias (Eletronorte, Chesf, Furnas e Eletrosul) vão aumentar os investimentos nos próximos anos. 0 presidente da Eletrobras, Jose Antonio Muniz Lopes, disse ontem que o grupo investirá $R \$ 47,5$ bilhões até 2014 , acima dos $\mathrm{R} \$ 45$ bilhões previstos inicialmente. $O$ consumo está crescendo forte. Um crescimento médio de $10 \%$ ao ano, nos próximos sete anos, significa que o mercado vai dobrar. Então, tem que investir mesmo - afirmou Muniz (ORDOÑEZ, R. Eletrobras investe R\$ 47,5 bi até 2014. O GLOBO, 22 Dez. 2010, p. 37).

Caso não se construam e entrem em operação a tempo as hidroelétricas previstas, o apagão será inevitável. [...] Há desemprego e pobreza com energia elétrica, mas, se o crescimento da economia não for sustentado pelo aumento da oferta de energia, não haverá chance de se gerar empregos e combater a miséria (O GLOBO, 6 ago. 2007, p. 6).

Em menor quantidade, algumas reportagens trataram das vantagens sociais do crescimento econômico, a exemplo do excerto abaixo:

O objetivo é garantir aos municípios não apenas compensações, mas a melhoria da qualidade de vida, mostrando que o desenvolvimento pode gerar diferentes recursos, que não se refletem apenas no aumento da receita do ISS (Imposto Sobre Serviços), destinado às prefeituras (ELETROBRAS, 2008, p. 24).

Neste artigo, a Gazeta do Povo apresenta as vantagens ambientais das novas estratégias para manutenção da oferta de energia por meio de novas usinas:

As hidrelétricas em planejamento são projetadas levando em consideração o mínimo impacto. Os projetos ambientalmente danosos são descartados. 0 empreendedor não investe em projetos ambientalmente danosos. Portanto, a avaliação ambiental é item prioritário quando se inicia um projeto. Foi-se o tempo dos projetos estruturantes nesta região do país, como a Usina de Itaipu e as do Rio Iguaçu, com potência superior a $1.000 \mathrm{MW}$, grandes reservatórios e grandes obras. A meta era implantar a maior potência possível. Atualmente, os projetos são bem menores. Até porque fontes renováveis, como a hidrelétrica de baixa potência, são certificadas no Mecanismo de Desenvolvimento Limpo (MDL) do protocolo de Kyoto, geram créditos de carbono, sendo certificadas ambientalmente por entidades ligadas à ONU. Desde o início das obras, são traçados planos ambientais de sustentabilidade (RIBAS, 2008).

Nota-se que, diferentemente das viabilidades social e ambiental, a econômica embasou justificativas de forma determinante para a construção de novos empreendimentos energéticos. Observou-se ainda que, enquanto os impactos socioambientais são tratados nos projetos como passíveis de compensação, seriam refutados projetos de rentabilidade nula ou não atrativa em relação às taxas esperadas pelo mercado ou que esse ônus fosse compensado com ganhos socioambientais. 


\section{EVIDENCIAÇÃO DE CONFLITOS: ECONÔMICOS, AMBIENTAIS E SOCIAIS}

$\mathrm{O}$ aspecto central observado nesta categoria se refere às contradições resultantes da busca por crescimento econômico. A proporção das reportagens classificadas como retratando conflitos majoritariamente econômicos foi pequena, apenas $16 \%$. Cabe ressaltar que, embora retratassem conflitos e contradições econômicas dos envolvidos, não foram encontradas reportagens que questionassem a sustentabilidade da busca pelo crescimento econômico ilimitado. Belo Monte foi o empreendimento cujas reportagens retratavam contextos controversos sobre sua viabilidade econômica, considerando os custos financeiros dos impactos socioambientais, vide exemplo:

Mas com esse tanto de problema ainda compensa ser o empreendedor de Belo Monte? Luiz Fernando Rufato - Já era previsto esse custo. Poderia ser mais barata a energia se não tivesse esse custo que foi empurrado para nós e teria sido para qualquer um que entrasse no leilão. Porque teve pouca gente que entrou no leilão? Não foi por causa do custo da obra. Foi por causa desses problemas todos sociais e ambientais e que tinha que ter a mão do governo para resolver, senão não saía [a obra]. Isso é para você entender o tamanho do empreendimento e o tamanho das preocupações (GLOBO.COM, 2011).

As questões ambientais estavam presentes em $49 \%$ da categoria 'conflitos'. A predominância do tema é relacionada ao relato de falhas e negligências nos estudos de avaliação dos impactos ambientais na construção dos empreendimentos e suas consequências durante a execução das obras de instalações das novas usinas. As reportagens dessa categoria referem-se, com frequência, às fragilidades dos estudos sobre impactos ambientais, muitos deles denunciados pela sociedade ao Ministério Público.

A usina de Belo Monte, uma das obras do PAC, esbarrou no Ibama. Os analistas da diretoria de licenciamento ambiental concluíram que é deficiente o relatório de impacto ambiental apresentado pela Eletrobras e por um consórcio de empresas (FRANCO e EBOLI, 2009, p. 2).

Para o secretário, a falta de cuidado em relação à existência de uma mina de carvão na região da hidrelétrica é uma deficiência do estudo de impacto ambiental. Não é para alarmismo, mas é um passivo ambiental (BREMBATTI, 2007).

[...] organizações não governamentais e o Ministério Público denunciam a fragilidade dos estudos de impacto ambiental das hidrelétricas, a falta de transparência nas relações com as comunidades afetadas e o rolo compressor patrocinado pelo governo para aprovar projetos a toque de caixa (JASPER, 2010).

Segundo os MPs federal e estadual, os rejeitos expostos e sem tratamento não foram adequadamente avaliados no Estudo de Impacto Ambiental nem no processo de licenciamento (JASPER, 2007).

As reportagens também evidenciaram que a busca pelo desenvolvimento baseado no crescimento econômico impacta o meio ambiente e seus danos têm sido mensurados financeiramente, em uma racionalidade que possibilita chegar a uma equação com variáveis de igualdade impossível. A ameaça de desequilíbrio ambiental é convertida em ônus financeiro, interface que permite mensurar o valor gasto com compensações analisadas sob a ótica da viabilidade econômica. "Todo investimento na comunidade e no meio ambiente, sendo transparente, tem retorno e é perfeitamente mensurável" disse o diretor da Brookfield Energia Renovável, Antônio Fonseca dos Santos (JASPER, 2010). O produto desse processo é a possibilidade de criar a relação 'custo' socioambiental versus benefício econômico.

A dimensão social foi a segunda mais presente na categoria evidenciação de conflitos. Os conflitos relatados envolvem principalmente as comunidades afetadas, cujo tema predominante foi 'povos indígenas'. No Estado do Pará, as comunidades indígenas se opõem há mais de 20 anos à construção das usinas de energias próximas às suas terras, pois temem a escassez de recursos de suas fontes tradicionais de sobrevivência: a caça e a pesca (FLEURY e ALMEIDA, 2013). 
Dez reportagens relatavam falta de diálogo com as comunidades indígenas e que isso agravou os conflitos entre os empreendimentos ao longo das bacias dos rios da Amazônia. Representantes de organizações não governamentais acusaram o Governo Federal de ter negligenciado as opiniões dos povos indígenas, que eram contrários aos empreendimentos, por entender que afetavam seus modos de vida. Seguem alguns excertos:

O Presidente do Conselho Indigenista Missionário (Cimi) e bispo prelado do Xingu, Dom Erwin Krautier, se declarou indignado com a licença prévia para construção de Belo Monte, no rio Xingu (PA). Ele disse que $o$ ato é uma demonstração de autoritarismo contra a democracia brasileira e um desrespeito ao povo da região do Xingu (HEBERTH, 2010, p. 25).

Cerca de 200 indígenas, afetados pela construção de hidroelétricas, ocuparam ontem o principal canteiro de obras da Usina de Belo Monte no município de Vitória do Xingu, no Pará. Eles reivindicam a regulamentação da consulta prévia e a suspensão das obras e estudos relacionados às barragens nos rios Xingu, Tapajós e Teles Pires. A tropa de choque da polícia militar já esperava pelos índios, mas não conseguiu barrá-los (LESSA, 2013, p. 35).

Os munduruku ocuparam o canteiro de obras da Usina Hidrelétrica de Belo Monte no fim de maio e, este mês, estiveram em Brasília, com mais de 140 índios, para se reunir com o secretário-geral da Presidência, Gilberto Carvalho (AGÊNCIA BRASIL, 2013).

Ainda com o intuito de ilustrar o contexto das reportagens que contrastaram com os relatórios, sem, no entanto, limitá-lo a esse excerto, expõe-se uma dentre as várias situações de conflitos sociais presentes na construção da usina Belo Monte, no rio Xingu:

Para justificar a invasão, os indígenas divulgaram uma carta na qual afirmam que são "a gente que vive nos rios e vocês querem construir barragens. Vocês estão apontando armas na nossa cabeça".

"Vocês sitiam nossos territórios com soldados e caminhões de guerra. Vocês fazem o peixe desaparecer", diz o documento. "[...] O que nós queremos é simples: vocês precisam regulamentar a lei que regula a consulta prévia aos povos indígenas. Enquanto isso, vocês precisam parar todas as obras e estudos e as operações policiais nos rios Xingu, Tapajós e Teles Pires", diz a carta nos parágrafos finais (ESSA, 2013, p. 35).

Pôde-se observar pelo corpus analisado que as empresas têm o apoio do Governo Federal para viabilizar a construção dos empreendimentos energéticos. Assim, resistir ou tentar impedir o avanço das hidroelétricas sobre o entorno de comunidades tradicionais e indígenas é uma tarefa desafiadora, pois existe grande discrepância do poder de mobilização de capitais econômicos e políticos entre empresas e comunidades tradicionais.

\section{ANÁLISE DE DISCURSO}

A seguir, descrevemos o processo de análise de discurso na busca da ideologia que significa a linguagem do discurso do desenvolvimento sustentável nos relatórios anuais das empresas selecionadas. Vale ressaltar que os fragmentos textuais apresentados ao longo das próximas seções foram trazidos apenas com o intuito de facilitar a compreensão do leitor. Ressalta-se, no entanto, que o produto da análise não se limita a eles. Esses excertos são parte de um discurso materializado nos textos e suas reais significações só podem ser obtidas na textualidade do material de que foram extraídos - textualidade sintetizada ao longo desta análise. O sentido não está, pois, nas palavras, mas materializado em sua discursividade. Não são as palavras que significam por si, mas sim o texto, em suas propriedades - em sua textualidade -, em seu contexto sócio-histórico, que opera a significação, em conjunto com a escolha das palavras em questão.

Apresentaremos a análise em 4 subseções: as significações enxergadas para (i) 'desenvolvimento' e de 'desenvolvimento sustentável' nos documentos analisados, (ii) sustentabilidade ambiental, (iii) sustentabilidade econômica e (iv) sustentabilidade social. 


\section{A SIGNIFICAÇÃO DE ‘DESENVOLVIMENTO’ E DE ‘DESENVOLVIMENTO SUSTENTÁVEL’ NOS RELATÓRIOS DE SUSTENTABILIDADE}

O discurso do desenvolvimento sustentável foi compreendido como a materialização de uma ideologia que o permite adquirir significações sustentadas por sujeitos emissores (nesse caso organizações) e que, embora se coloquem na condição de ativos, são sujeitos passivos de um discurso materializado na linguagem, pelo contexto sócio-histórico.

O primeiro contato com os textos ocorreu com a latência das perguntas: para quem esta mensagem está sendo emitida, e como ela significa no contexto do receptor? Embora as informações contidas nos relatórios sejam de interesse público, por relatar ações que visam ao desenvolvimento sustentável, com o decorrer das leituras evidenciou-se que, mais do que para o público geral, os relatórios são direcionados aos integrantes do campo do mercado de capitais. Chegou-se a esse entendimento notando a linguagem empregada, predominantemente economicista, evidenciando investimentos financeiros em áreas de preservação, projetos sociais e filantropia. No entanto, tal linguagem é incapaz de evidenciar resultados socioambientais dissociados de índices econômicos. A adesão à metodologia do Global Reporting Initiative (GRI) ${ }^{7}$ converge para uma tentativa de facilitar o trabalho comparativo dos investidores, mediante uma linguagem uníssona.

Notou-se que 'sustentabilidade' é um adjetivo amplamente utilizado como qualificador para quaisquer substantivos concretos, a exemplo de 'planeta sustentável' (CEMIG, 2007, p. 3) ou abstratos, como 'destino sustentável' (COPEL, 2011, p. 92). Quando dita, aciona sentidos de uma memória discursiva e, ao mesmo tempo que traz o já dito, também é contextualizada em interdiscursos influenciados pelo sistema econômico vigente, formando neologismos, expressões e significações de virtuosidade do modelo desenvolvimentista.

No discurso analisado, sustentabilidade tem caráter polissêmico (dentre as significações possíveis determinadas pela ideologia dominante) e, propositalmente nesse campo, converge para associação àquilo que supostamente evita a crise econômica, social e ambiental, contextualizada com a intencionalidade das empresas em ser reconhecidas como sustentáveis. Foram encontrados neologismos e composições de termos e expressões polissêmicas que derivam da ideologia que se manifesta no discurso do desenvolvimento sustentável, tais como 'crescimento econômico sustentável', 'crescimento sustentável', 'empresa sustentável', 'energia sustentável', 'expansão sustentável', 'gestão sustentável', dentre vários outros.

Entretanto, afinal, antes de ser sustentável, de que maneira figura o significado de 'desenvolvimento'? Nos relatórios, o termo tem sentido tão amplo e abstrato quanto vazio. Todas as empresas cujos discursos foram analisados afirmam buscá-lo, mas não há nenhuma explicitação de sua delimitação para que se pudesse avaliar ou mensurar seu alcance definitivo, se foi ou se será atingido de forma satisfatória.

\section{SUSTENTABILIDADE AMBIENTAL}

A dimensão ambiental presume o desenvolvimento equilibrado com as dimensões social e econômica do 3BL. Nota-se que existe forte influência das correntes de pensamento antropocentristas na construção de sentidos para essa dimensão. Chega-se a essa constatação pelo fato da naturalização da supremacia humana sobre a natureza, objetivada e subalterna às transformações resultantes dos modos de produção e dos padrões de consumo, na busca do crescimento econômico.

Latouche (2009) lembra o quão reduzido e objetivado foi o conceito de natureza, passando a ser mera fonte de recursos e, ao mesmo tempo, depósito dos resíduos, eliminando a possibilidade de compensação na mesma proporção dos danos causados, resultando, invariavelmente, em desequilíbrio ambiental irreversível. A humanidade se autoriza a alterar o ambiente (por meio de legislação) e gerir os impactos da forma que menos lhe causar prejuízos em nome do desenvolvimento sustentável:

O acompanhamento rigoroso dos impactos socioambientais decorrentes das operações da Cemig é imperativo para garantir a continuidade e crescimento equilibrado da Companhia. A utilização

\footnotetext{
7 Os relatórios de sustentabilidade no Brasil têm sido elaborados conforme a metodologia do Global Reporting Initiative (GRI). Esta metodologia é mundialmente difundida e consiste numa tentativa de padronização destes relatórios para divulgação ao mercado global.
} 
responsável e inteligente dos recursos disponíveis visa [a] melhorar a qualidade de vida da sociedade e, simultaneamente, reduzir os riscos econômico-financeiros aos quais a Empresa está submetida (CEMIG, 2011, p. 21, grifo nosso).

Como observado, 'sustentabilidade ambiental', no contexto das empresas, presume que toda atividade de geração de energia produzirá algum impacto ambiental; porém, considera-se que são impactos inevitáveis diante da necessidade de suprir a demanda por energia e que a energia gerada a partir das usinas hidroelétricas tem menor impacto em relação às outras fontes de geração, sempre comparadas com as usinas nucleares e termoelétricas, reconhecidamente mais poluentes. A significação de energia sustentável é constituída a partir de interdiscursos que consideram as hidroelétricas como fontes ideais para o contexto mundial. Essas correntes defendem essa matriz energética pelo fato da baixa emissão de gás carbônico (CO2), um dos gases causadores do efeito estufa. Nos relatórios analisados, a energia proveniente de hidroelétricas é significada como energia limpa e renovável. A predominância das hidroelétricas no contexto brasileiro é tida como fator positivo para o país, uma vez que existem inúmeras regiões com bacias hidrográficas favoráveis a instalações de novas usinas, o que possibilita o aumento da oferta de energia para garantia do crescimento econômico do país.

Na maioria dos relatórios - exceto os da Eletrobras -, as pequenas usinas hidroelétricas são tidas como empreendimentos de baixo impacto. Essas usinas não necessitam de grandes reservatórios e, consequentemente, acabam inundando áreas menores, aproveitando as condições naturais favoráveis, como quedas e saltos d'água, para a instalação das turbinas. Ao oposto está o empreendimento da Usina de Belo Monte, cujo gigantismo é significado no relatório como símbolo de desenvolvimento, e toda a argumentação para produção de sentidos dos aspectos positivos se dá em função de sua capacidade instalada de geração de energia. O uso do qualificador sustentável para caracterizar vantagens, tanto das pequenas quanto das grandes usinas, evidencia a flexibilidade do uso do termo dissociado de consenso técnico sobre os impactos causados em função do porte das instalações.

Nota-se que as correntes discursivas que geram sentido para as ações compensatórias dos impactos causados no meio ambiente são influenciadas pelo pensamento econômico, uma vez que demonstrações de esforços são significados a partir da valorização da mensuração dos investimentos financeiros despendidos para manutenção dos programas. Tentativas de contabilização financeira de aspetos ambientais são descabidas, pois a mensuração financeira dos danos ao capital natural é imperfeita (LATOUCHE, 1998). A precificação do meio ambiente demonstra ser uma simples objetivação desconexa de sua complexidade orgânica, desconsiderando que os impactos ambientais vão além da área das instalações dos empreendimentos.

\section{SUSTENTABILIDADE ECONÔMICA}

Os relatórios de sustentabilidade significam por meio da linguagem econômica. É por meio da mensuração financeira dos investimentos, dos riscos, dos impactos e dos projetos que o 3BL faz sentido, pois, para criar harmonia entre aspectos econômicos, sociais e ambientais, a linguagem comum é a da moeda corrente. Tanto os impactos do projeto quanto os resultados esperados do empreendimento são analisados sob a ótica econômica. Isso significa que todos os impactos, inclusive o bem-estar social e a preservação ambiental, devem ser avaliados em relação ao risco financeiro e econômico para a empresa, seja por meio de multas, pela desvalorização da imagem no mercado etc.

Por se tratar de uma ideologia, são as empresas falando, mas da ideologia materializada no discurso falando por meio delas. Eles representam a hegemonia economicista no constructo do conceito de desenvolvimento sustentável. As correntes discursivas que mantêm o 3BL possuem capacidade de produzir e reproduzir sentidos, favorecendo sua lógica. $\mathrm{O}$ crescimento econômico é o balizador objetivo do desenvolvimento sustentável: crescer é bom, não crescer é ruim e a determinação do bom ou ruim é numérica e objetiva.

É necessário destacar, em primeiro lugar, que esta expansão foi cuidadosamente planejada e consta do nosso Plano Diretor, desde 2004, sempre com o foco na orientação de crescer com sustentabilidade, ou seja, fazer uma expansão com rentabilidade, mantendo a solidez de nosso balanço e ampliando a nossa posição no cenário de energia elétrica do Brasil e com a firme posição de agregar valor para os nossos acionistas (CEMIG, 2009, p. 14). 
O atendimento das necessidades da geração atual e das gerações futuras, pensadas há mais de 40 anos, ganha atributos que antes não o compunham. Nota-se que no discurso analisado, no rol de necessidades está a de garantir o retorno financeiro aos acionistas da geração atual. Dessa forma, as ações das empresas continuarão valorizando-se no mercado de capitais, o que possibilita a captação de recursos para fomentar o desenvolvimento de novas tecnologias e investimentos socioambientais. Assim, serão viabilizadas as compensações dos impactos causados e admitidos pelo próprio desenvolvimento sustentável. Nesse contexto, é por meio da solidez financeira e econômica que se obtém a sustentabilidade. As compensações se concretizam com recursos provenientes de lucros (re)aplicados, passando a ideia de um ciclo virtuoso.

Destarte, desenvolvimento sustentável é mais dependente da prosperidade econômica do que da minimização dos impactos socioambientais. Estes são passíveis de compensações posteriores subsidiados pelo capital dentro de sua própria análise de viabilidade econômica. Isso, na ideologia do crescimento que sustenta o discurso, não invalida o argumento de que no 3BL deve haver harmonia entre as três dimensões. Basta que, pelos constructos de interpretação da realidade por meio de dados econômicos, sejam provadas as intervenções ou intenções de ações de compensação de impactos viabilizadas pelas atividades da empresa, assim, o círculo virtuoso se fecha, sendo, portanto, consideradas sustentáveis.

\section{SUSTENTABILIDADE SOCIAL}

A mensuração do desenvolvimento social também é economicista. O símbolo dessa compreensão da realidade social é a ferramenta de análise mais popular entre os relatórios: o balanço social. Nas tabelas dessas demonstrações, os aspectos sociais são representados em números. Não há subjetividade, identidade cultural, tampouco modo de mensurar aspectos mais substantivos do modo de vida daquelas comunidades, senão os monetarizando. Da mesma forma, os aspectos sociais internos da empresa cabem em tabelas numéricas para facilitação de comparação entre outras empresas que se descrevem de forma uníssona, a saber: aos moldes da ideologia do crescimento econômico inerente à metodologia GRI.

O discurso remete à harmonia com a comunidade. Não são presentes relatos de fatos de conflitos que ainda não tenham sido superados, mas somente a divulgação das soluções cabidas legalmente, como se fossem uma iniciativa dessas empresas. O discurso da sustentabilidade social significa como uma possibilidade de chegada do desenvolvimento, de forma compensatória. Nessa narrativa unilateral, o final é sempre conciliatório.

Sustentabilidade social é significada como filantropia, cumprimento da legislação, investimentos culturais, compensação à comunidade por danos causados, cumprimento das leis trabalhistas e promoção da saúde ocupacional. A responsabilidade social chega a se confundir com o cumprimento de obrigações legais, como as ações de prevenção de acidentes de trabalho e exames de saúde ocupacional. Também são presentes os relatos de profissionalização dos colaboradores, voluntariado, programas educacionais para a comunidade e incentivo financeiro a programas sociais. $O$ incentivo para que sejam realizadas ações de cidadania materializa o significado de que, dessa forma, a empresa está impactando positivamente seu entorno com a capilaridade da rede de contato social de seus próprios colaboradores.

\section{DISCUSSÃO: ANÁLISE DE CONTEÚDO E DE DISCURSO CONTRAPOSTAS}

A seguir, apresentamos uma análise dialética entre os resultados da análise de conteúdo e a análise de discurso. Discutiremos os resultados das duas análises de forma dialética, à luz das dimensões de ideologia propostas por Giddens (1979), assim ordenadas: (i) representação de interesses particulares como coletivos; (ii) negação das contradições; e (iii) reificação do presente.

\section{Representação de interesses particulares como coletivos}

O que é, então, o 'desenvolvimento sustentável’? É aquilo que o economicismo determina que seja socialmente responsável e ecologicamente correto, mas invariavelmente viável para os investidores. Como lembra Latouche (1994), o crescimento econômico aliado ao desenvolvimento é tido como a apoteose da modernidade. É pela ideologia do crescimento econômico que as empresas listadas no ISE BM\&FBOVESPA acreditam no desenvolvimento sustentável e reproduzem as crenças da 
necessidade dessa virtuosidade no atual sistema econômico. Para a pergunta "por que todas essas as organizações discursam a sustentabilidade?", a resposta é tautológica, "porque todas elas discursam a sustentabilidade", uma vez que são agentes passivos do discurso dominante.

É mediante essa linguagem de resultados que se obtêm as premiações e troféus de 'empresa sustentável'. Para ser sustentável no contexto desse grupo de empresas é necessário sustentar o discurso que permite que o ISE BM\&FBOVESPA exista para nele permanecer. O discurso não se iniciou com a criação desse índice, embora também seja construído por ele (leia-se, seus interessados). Não são as empresas listadas no ISE BM\&FBOVESPA que determinam o que é sustentável, mas a ideologia dominante que se baseia no crescimento econômico como meio e como fim, formando um círculo fechado de ideias.

Nossos resultados corroboram Banerjee (2008), para quem o desenvolvimento se tornou sinônimo de crescimento econômico. Para o capital, não há limite para a maximização do lucro (FOLADORI, 2001); consequentemente, os interesses das empresas serão sobrepostos aos das comunidades e aos de preservação do meio ambiente. No entanto, tais interesses são ressignificados por meio da ideologia para que pareçam beneficiar equitativamente as três dimensões do 3BL. Como afirma Banerjee (2008), a retórica do 3BL mantém as questões sociais e ambientais simplesmente porque são capazes de impulsionar os ganhos econômicos.

No conteúdo das reportagens ficou evidente que a maioria dos fatos noticiados sobre uma visão desenvolvimentista se referem às vantagens econômicas do desenvolvimento sustentável. Isso, nos relatórios, é retoricamente equalizado como vantajoso para a comunidade e para a preservação do meio ambiente. No entanto, a prioridade gerencial está na maximização do lucro do acionista, tornando as questões ambientais e sociais tópicos secundários (SEIFERT e VIZEU, 2015a).

Toda significação do desenvolvimento sustentável ocorre com a argumentação da harmonização do 3BL, sendo que o bem-estar da população é apresentado na dimensão social por meio da garantia do fornecimento de energia à população brasileira, por cada empresa, em sua área de abrangência.

A chegada dos empreendimentos hidroelétricos (predominantes na matriz energética de todas as empresas analisadas) significa no discurso o anseio das comunidades locais pelo progresso, aos moldes do discurso do desenvolvimento sustentável. O legado às cidades do entorno, os deslocamentos de famílias de áreas inundadas para residências aos moldes urbanos, por exemplo, são discursados de modo a significar a harmonia da distribuição dos benefícios entre os interessados e afetados. No entanto, é possível constatar, pela desproporção entre as reportagens que abordam os benefícios econômicos do crescimento das empresas analisadas e as que retratam conflitos sociais, que os afetados pelos impactos nem sempre têm as recompensas compatíveis com os que possuem interesse econômico nos empreendimentos. Banerjee (2003) aborda essa dissimulação do desequilíbrio entre as dimensões, o que torna os investidores os maiores beneficiados:

Este processo "sustentável" é elogiado por corporações e governos por criarem oportunidades de emprego para as comunidades locais, mas eles não reconhecem a fragilização e a pobreza criadas como resultado da desapropriação de terras e recursos naturais. No discurso do desenvolvimento sustentável, a pobreza é identificada como o agente da destruição ambiental, legitimando assim as noções anteriores de crescimento e desenvolvimento (BANERJEE, 2003, p. 159).

As comunidades indígenas, em sua tradição, são menos dependentes de energia elétrica. Algumas tribos isoladas da Amazônia sequer a utilizam. No entanto, quando anunciados os benefícios dos empreendimentos hidroelétricos, o ônus de interferir no equilíbrio da vida das comunidades indígenas (máquinas, estradas, alterações mesmo que indiretas no meio ambiente) é ressignificado como a possibilidade da chegada do progresso. Nós, 'desenvolvidos' - sociedade ocidentalizada -, necessitamos de energia para manter o crescimento econômico eo padrão de conforto e consumo do qual dependemos, mas são as comunidades cujo modo de vida menos se assemelha ao nosso que alteram seus modos de viver em função de nossa dependência de energia elétrica. Em troca se oferece o desenvolvimento, o próprio causador dos impactos.

\section{Negação das contradições}

A negação das contradições como primeiro critério ideológico indicado por Giddens (1979) é aplicado ao contexto organizacional por Seifert e Vizeu (2015a, p. 130) como mecanismo de manutenção do status quo, onde "a ideologia se constitui 
como uma representação que distorce a realidade dos fatos de tal forma que o sistema social pareça ser equilibrado, justo e necessário". Foi possível notar contradições comparando os significados do discurso para as dimensões do 3BL, e as evidências trazidas a partir do conteúdo midiático. A seguir, serão exploradas duas contradições negadas no discurso do desenvolvimento sustentável.

A primeira contradição negada é a da desarmonia entre as dimensões do 3BL. Pelo discurso do desenvolvimento sustentável, o crescimento ocorre harmonizando os aspectos sociais, ambientais e econômicos. Nos relatórios, não existem menções aos graves conflitos que envolvem, inclusive, violência física entre comunidade e representantes das empresas narrados em reportagens. Foram vários os protestos, invasões dos campos de obra (a maioria em Belo Monte-PA), ameaças e agressões a um representante da Eletrobras esfaqueado em 2008 (BRASILIENSE, DOCA, PAUL et al., 2008) que sequer foram mencionadas nos relatórios. Algumas reportagens denunciaram a falta de diálogo com as comunidades indígenas, apesar da Eletrobras informar ter realizado pelo menos 30 reuniões até 2010 , além de 12 audiências públicas.

Apesar da significação harmoniosa dos relatos contidos nos relatórios sobre os relacionamentos com as comunidades locais, a análise de conteúdo possibilitou notar a expressiva quantidade de conflitos ambientais e sociais. As realidades do discurso dos relatórios e das reportagens parecem distintas. Logo, nota-se uma disparidade entre impactos positivos e negativos: vantagens econômicas em detrimento da tolerância dos impactos socioambientais. Esse aspecto evidencia a contradição lógica do desenvolvimento sustentável (VIZEU, MENEGHETTI e SEIFERT, 2012) e a desarmonia das ações práticas dissimuladas pela retórica do 3BL (BANERJEE, 2008), abordagem base na elaboração dos relatórios de sustentabilidade.

A segunda contradição aqui abordada se refere ao pressuposto da aceitação dos empreendimentos de geração de energia pelas comunidades afetadas. No discurso ideológico do crescimento, as contradições dos conflitos são negadas por meio da ressignificação eufêmica da realidade material em algum grau acessada pelas reportagens. Os relatórios - quando abordam a interação com a sociedade - produzem o sentido de que os empreendimentos são bem vistos, desejados e benéficos à comunidade. No entanto, a partir do relato de fatos contidos no corpus da análise de conteúdo, deparou-se com uma realidade distinta ao diálogo cordial entre as empresas, o Estado e as comunidades. Esse posicionamento do mercado remete ao discurso do presidente Truman, de 1949, que instituiu a missão de levar desenvolvimento àquelas nações que não tinham o mesmo perfil econômico dos EUA (ESCOBAR, 1995; BANERJEE, 2008; SACHS, 2010; VIZEU, MENEGHETTI e SEIFERT, 2012). A postura colonizadora de levar a solução ao outro pressupondo portar o modelo apoteótico de desenvolvimento a comunidades tradicionais se reflete na contradição entre discurso e relatos de recepção dos empreendimentos nas comunidades. Além dessa postura, o foco na viabilidade econômica dos empreendimentos faz com que o desenvolvimento sustentável seja um modelo a ser construído sob as consequências dos impactos, sofridos principalmente por aqueles que estão às margens dos benefícios econômicos obtidos.

À sociedade desenvolvida cabe manter o crescimento econômico e o padrão de conforto e consumo do qual dependemos; mas são as comunidades cujo modo de vida menos se assemelha ao nosso que alteram o modo de viver, em função dessa dependência. Em troca, oferece-se o desenvolvimento, o próprio causador dos impactos: nosso problema com a solução aos nossos moldes - ecoando a representação de interesses particulares como coletivos, previamente abordada nesta análise.

Questiona-se, então: porque há tantos conflitos relatados nos jornais, em meio a um processo de desenvolvimento sustentável discursado como aberto e harmonioso? Faz sentido, aqui, a abordagem de Latouche (1994), quando observa a imposição do modelo desenvolvimentista ocidental às culturas tradicionais, operacionalizado pelo Estado-nação, com finalidade de atender às necessidades das classes dominantes, resultando em etnocídio e no agravamento do desequilíbrio do ecossistema.

\section{REIFICAÇÃO DO PRESENTE}

Aliado à negação de contradições está o atributo ideológico que transforma a noção que temos do status quo em uma fatalidade ou em algo natural: a prescrição da ideologia considerada natural será percebida como inevitável (SEIFERT e VIZEU, 
2015a, p. 130). A reificação do presente tem papel fundamental na ressignificação das contradições do crescimento econômico. Se o discurso dominante conduz ao entendimento de que não existe outra possibilidade senão crescer, a admissão da necessidade do crescimento econômico se torna mais fácil. Os conflitos tornam-se uma consequência tão inevitável quanto a necessidade de crescer, pois não há alternativas; o presente está naturalizado. O aspecto econômico torna-se, então, um campo autônomo da vida social e justifica-se por si (LATOUCHE, 1994).

Confrontando o discurso da sustentabilidade com as reportagens que associam o tema às empresas analisadas foram encontrados vários elementos que caracterizam a naturalização do presente. O primeiro é a necessidade de crescimento econômico ilimitado. Como descrito por Gómez (2002), o desenvolvimento aos moldes da economia toma proporções de um destino 'onibenéfico' e inexorável para a sociedade. Para que o desenvolvimento seja alcançado, é necessário crescer economicamente, com danos colaterais que o próprio constructo afirma resolver. Para Banerjee (2008) há pouca criticidade na mídia, na academia e na recepção desses discursos. Embora com notáveis contradições lógicas, é naturalmente aceito e defendido pelo mercado sem quaisquer restrições quando se adjetiva o crescimento como sustentável. Embora tenha se tornado um conceito vago a ponto de tornar-se vazio (SHAMIR, 2005), a palavra 'sustentável' é capaz de preencher qualquer contexto com atributos virtuosos e o crescimento é um componente indissociável dessa virtuosidade. $O$ segundo elemento aqui analisado trata da naturalização da necessidade de admissão dos impactos do crescimento econômico: se o crescimento é o único meio de obter desenvolvimento nos moldes do 3BL, e para obter-se crescimento é necessária geração de energia, os impactos são tão inevitáveis quanto necessários. Em nome de um bem maior (que atende aos interesses dos grupos econômicos dominantes) que é o progresso produtivista, quaisquer impactos serão (forçadamente) mitigados com compensações financeiras, significadas ideologicamente para justificação da continuidade desse modelo predatório de desenvolvimento sustentável. Para Latouche (2009), esse é o argumento do mercado para manutenção de seu crescimento e sua essência está na crença de que será possível compensar os danos com reinvestimentos nos âmbitos ambientais e sociais. Trata-se de uma lógica viciosa (SEIFERT e VIZEU, 2015a; VIZEU, MENEGHETTI e SEIFERT, 2012), uma vez que a causa é a solução para o próprio problema.

\section{CONSIDERAÇÕES FINAIS}

A análise de discurso permitiu compreender como os aspectos do 3BL significam no atual discurso do desenvolvimento sustentável das empresas estatais do setor de geração de energia listadas no ISE BM\&FBOVESPA. Por meio desta análise, demonstrou-se que o desenvolvimento sustentável é regido pela ideologia econômica do crescimento. Já a análise do conteúdo jornalístico apontou a existência de muitos conflitos que permeiam o crescimento das empresas de geração de energia. Mesmo com o viés do interesse econômico que as mídias tendem a (re)produzir em suas edições jornalísticas - respeitando a imagem de seus anunciantes (as próprias empresas de geração de energia) -, foi possível encontrar temas de conflitos que deixaram clara a materialidade das contradições lógicas do desenvolvimento sustentável. Fica evidente que, nesse modelo de desenvolvimento, enquanto as vantagens são econômicas, os conflitos ocorrem nas esferas social e ambiental.

No contexto do setor analisado, notou-se forte ingerência do Estado, tanto na gestão das empresas quanto na utilização dos poderes Legislativo e Executivo para articular o crescimento da economia por meio da garantia de oferta de energia necessária. O que determina o que é legalmente, socialmente e ambientalmente correto? A ideologia baseada no pensamento econômico como forma de organizar a sociedade determina a compreensão do que é sustentável e do que é insustentável. De que forma isso ocorre? Por meio das instituições autorizadas para fazê-lo, em última instância, regulamentadas pelo próprio Estado, cujos interesses ora se confundem com os interesses dos agentes detentores de poder econômico que operam no mercado.

O que é, então, o 'desenvolvimento sustentável'? É aquilo que o economicismo determina que seja: socialmente responsável e ecologicamente correto, mas invariavelmente viável em termos financeiros. É pelo mecanismo ideológico que as empresas listadas no ISE BM\&FBOVESPA acreditam no desenvolvimento sustentável e reproduzem as crenças da necessidade dessa virtuosidade no atual modelo de desenvolvimento baseado no crescimento econômico. Para a pergunta "por que todas essas organizações discursam a sustentabilidade?", a resposta é tautológica, "porque todas elas discursam a sustentabilidade". Como são players de um campo, o mercado de capitais, e desejam o reconhecimento desse campo - que é compor a carteira de investimentos sustentáveis -, vão sujeitar-se a protagonizar a reprodução do discurso da sustentabilidade nesse simulacro de desenvolvimento virtuoso. 
As dimensões do 3BL - ao invés de um tripé equitativamente equilibrado - demonstram estar desproporcionalmente dispostas: a dimensão econômica, sustentada por uma base dúplice, ambiental e social. Embora ressignificadas, as contradições permanecem e o crescimento econômico continua a se chocar com a finitude dos recursos do planeta (LATOUCHE, 2009; MEADOWS, RANDERS e MEADOWS, 2007). A dimensão econômica é mensuradora das métricas de viabilidade e, dentro de seus constructos lógicos, determina aquilo que pode ser compensado ou não por meio de gastos financeiros. Nesse simulacro, é até possível e aceitável que a atividade produtiva tenha impactos socioambientais negativos, porém viáveis, mas é intolerável que não se mantenha lucrativa.

Parece claro que que os componentes ideológicos do crescimento se transferem para o discurso do desenvolvimento sustentável mediante eufemismos e deslizes semânticos que possibilitam às organizações usufruir das propriedades polissêmicas da linguagem para ressignificá-las e, assim, lidam com as contradições da lógica desenvolvimentista que se sustenta com o discurso da sustentabilidade aos moldes do 3BL. Tais ressignificações são operadas pela ideologia econômica dominante e naturalizam a necessidade crescimento econômico. Como consequência, constrói-se uma 'sociedade de crescimento' como se esse fosse 'o' caminho natural, inexorável ou imutável. Essa realidade reificada é discursada como se atendesse aos interesses coletivos e, para isso, utiliza-se a retórica da responsabilidade ambiental e social como se estivessem em equilíbrio com o crescimento econômico. Característico do aspecto dominador da ideologia, o discurso romantizado e persuasivo dos relatórios de sustentabilidade cria uma aparência que obstrui, aos consumidores desses textos, a consciência das contradições e as consequências materiais do crescimento econômico, a exemplo daquelas que evidenciamos dialeticamente nesta pesquisa.

Nossa pretensão de compreender as ressignificações da ideologia do crescimento para lidar com as contradições lógicas do desenvolvimento (in)sustentável apresenta limitações. Elencamos duas principais, em relação à estratégia metodológica das quais temos ciência. A primeira se refere ao viés jornalístico na comunicação dos fatos relacionados às empresas. É importante esclarecer que a mídia noticiosa não está isenta de viés ideológico e, ao mesmo tempo que expressa (na maioria dos casos) os valores que circulam na sociedade, também opera para imprimir e conciliar visões que defende como corretas. Em uma tentativa ainda que limitada, buscamos analisar os dados midiáticos para além do espectador ou leitor a quem aquele material fora direcionado. A segunda limitação está no alcance dos relatos midiáticos, uma vez que não foi possível acessar reportagens para além dos jornais das cidades em que se localizam as sedes das empresas do caso. Como possibilidade para futuros estudos, vislumbramos uma análise aprofundada da realidade da construção de uma usina, triangulando dados primários obtidos com a população local, mediante entrevistas e narrativas coletadas, por exemplo.

Assim, sem apontar o 'modelo' ideal de sustentabilidade, parece-nos que o desapego voluntário da necessidade de crescimento ilimitado é uma das possibilidades em debate para desacelerar o processo de destruição da única casa até então conhecida que abriga a espécie humana e os demais seres vivos que garantem o equilíbrio para nossa existência: o planeta Terra. 


\section{REFERÊNCIAS}

AGÊNCIA BRASIL. Assessores do governo já estão no Pará para negociar com índios munduruku. Gazeta do Povo, 23 jun. 2013. Disponível: em: <http://www.gazetadopovo.com.br/vidaecidadania/conteudo. phtml?id=1384695>. Acesso em: 22 dez. 2014.

BAKHTIN, M. Marxismo e filosofia da linguagem. 12. ed. São Paulo: Hucitec, 2006.

BANERJEE, S. B. Who sustains whose development? Sustainable development and reinvention of nature. Organization Studies, v. 24, n. 1, p. 143-180, 2003.

BANERJEE, S. B. Corporate social responsibility: the good, the bad and the ugly. Critical Sociology, v. 34, n. 1, p. 51-79, 2008.

BARDIN, L. Análise de conteúdo. Lisboa: Ed. 70, 2010.

BRASIL. O PAC 2. Disponível em: <http://www.pac.gov.br/sobre-o-pac>. Acesso em: 11 fev. 2015.

BRASILIENSE, R. et al. Belo Monte: procuradoria quer licitação. O Globo, 22 maio 2008, p. 26. Disponível em: <http://acervo.oglobo.globo. com/?service=printPagina\&imagemPrint=http\%3A\%2F\%2Fduyt0k3aayxim.cloudfront.net\%2FPDFs_XMLs_artigos\%2Fo_globo>. Acesso em: 20 dez. 2014.

BREMBATTI, K. Descoberta de resíduos de carvão põe em risco construção de Mauá. Gazeta do Povo, 3 ago. 2007. Disponível em: <http:// www.gazetadopovo.com.br/economia/conteudo.phtml?id=684431>. Acesso em: 31 dez. 2014.

BRYMAN, A.; BELL, E. Business research methods. 3. ed. New York: Oxford. 2004.

CASTRO, C. J. Sustainable development. Organization \& Environment, v. 17, n. 2, p. 195-224, 2004.

COMISSÃO DE BRUNDTLAND. Comissão Mundial sobre Meio Ambiente e Desenvolvimento: o nosso futuro comum. 2. ed. Rio de Janeiro: Fundação Getulio Vargas, 1991.

COMPANHIA ENERGÉTICA DE MINAS GERAIS - CEMIG. Relatório de sustentabilidade 2007. Disponível em: <http://cemig.infoinvest.com. br/relatorios_anuais/2007/sources/portug/pdf/sustentabilid ade. pdf>. Acesso em: 4 mar. 2015.

COMPANHIA ENERGÉTICA DE MINAS GERAIS - CEMIG. Relatório de sustentabilidade 2009. Disponível em: <http://cemig.infoinvest. com.br/relatorios_anuais/2009/pdfs/relatorio_anual_2009_P.p df $>$. Acesso em: 4 mar. 2015.

COMPANHIA ENERGÉTICA DE MINAS GERAIS - CEMIG. Relatório anual de sustentabilidade 2011. 2011. Disponível em: <http://cemig.infoinvest.com.br/relatorios_anuais/2011/RelatorioCemig2012 final. pdf>. Acesso em: 4 mar. 2015.

COMPANHIA ENERGÉTICA DE MINAS GERAIS-CEMIG. Relatório anual e de sustentabilidade 2012. Belo Horizonte: Cemig, 2012. Disponível em: <http://ri.cemig.com.br/static/ptb/arquivos/relatorio_anual_sustentabilidade_2012_ptb.pdf>. Acesso em: 21 jan. 2017.

CORBETTA, P. Social research: theory, methods and techniques. London: Sage, 2003.
ELETROBRAS. Relatório de sustentabilidade 2008. Disponível em: $<$ http://www.eletrobras.com/elb/main.asp?Team=\%7B4A2B5B3C-751A-4E38-86A7D6085CEE347B\%7D\#2013>. Acesso em: 4 mar. 2015.

ELKINGTON, J. Cannibals with forks: the Triple Bottom Line of 21st century business. Oxford: Capstone, 1997.

ESCOBAR, A. Encountering development: the making and unmaking of the Third World. New Jersey: Princeton University Press, 1995.

ESSA, F. Índios voltam a paralisar obras de Belo Monte. O Estado de S. Paulo, 3 maio 2013, p. 35. Disponível em: <http://economia. estadao.com.br/noticias/geral,indios-paralisam-obra-de-belo-monte,152617e>. Acesso em: 30 ago. 2016.

ESTEVA, G. Development. In: W. SACHS (Org.). The development dictionary: a guide to knowledge as power. New York: Zed, 2010. 1-23 p.

FIORIN, J. L. Linguagem e ideologia. 4. ed. São Paulo: Ática, 1995.

FLEURY, L. C.; ALMEIDA, J. A construção da Usina Hidrelétrica de Belo Monte: conflito ambiental e o dilema do desenvolvimento. Ambient. soc., São Paulo, v. 16, n. 4, p. 141-156, Dec. 2013. Disponível em: <http://www.scielo.br/scielo.php?script=sci_arttext\&pid=S1414-753X2013000400009\&lng=en\&nrm=iso >. Acesso em: 24 Jan. 2017.

FOLADORI, G. Limites do desenvolvimento sustentável. Campinas, SP: Ed. Unicamp, 2001

FRANCO, I.; EBOLI, E. Na berlinda. O Globo, 7 maio 2009, p. 2. Disponível em: <http://acervo.oglobo.globo.

GIDDENS, A. Central problems in social theory: action, structure and contradiction in social analysis. London: Macmillan, 1979.

GLOBO.COM. Em Belo Monte, $20 \%$ são obras e $80 \%$ são problemas, diz consórcio. Gazeta do Povo, 6 jun. 2011. Disponível em: <http:// www.gazetadopovo.com.br/economia/conteudo.phtml?id=1133943>. Acesso em: 29 dez. 2014.

GÓMEZ, J. R. M. Crítica ao conceito de desenvolvimento. Revista Pegada, v. 3, n. 1, p. 1-13, 2002.

HABERMAS, J. Dialética e hermenêutica: para a crítica da hermenêutica de Gadamer. Porto Alegre: L\&PM, 1987.

HEBERTH, J. Bispo: "índios não foram consultados". o Globo, 3 fev. 2010 , p. 25.

ILLICH, I. Needs. In: SACHS, W. (Org.). The development dictionary: a guide to knowledge as power. New York: Zed, 2010. 95-110 p.

JASPER. F. MPs desaprovam licença para Mauá. Gazeta do Povo, 10 ago. 2007. Disponível em: <http://www.gazetadopovo.com.br/ economia/conteudo.phtml?id=686366\&tit=MPs-desaprovam-licenca-para-Maua>. Acesso em: 26 dez. 2014

JASPER, F. Setor discute redução de impacto de usinas. Gazeta do Povo, 30 jun. 2010. Disponível em: <http://www.gazetadopovo.com. br/economia/conteudo.phtml?id=1019784>. Acesso em: 23 dez. 2014.

LATOUCHE, S. A ocidentalização do mundo. Rio de Janeiro: Vozes, 1994. 
LATOUCHE, S. Os perigos do mercado planetário. Lisboa. Instituto Piaget, 1998.

LATOUCHE, S. Pequeno tratado do decrescimento sereno. São Paulo: Martins Fontes, 2009.

LEITÃO, M. Não adianta negar. O Globo, 30 jan. 2007, p. 20. Disponível em <http://acervo.oglobo.globo.

LESSA. F. Índios voltam a paralisar obras de Belo Monte. O Estado de S. Paulo, 3 maio 2013, p. 35.

MARCONATTO, D. A. B. et al. Saindo da trincheira do desenvolvimento sustentável: uma nova perspectiva para a análise e a decisão em sustentabilidade. Revista de Administração Mackenzie, v. 14, n. 1, p. 15-43, 2013.

MARCONDES, A. W. ISE: sustentabilidade no mercado de capitais. São Paulo: Report, 2010.

MATITZ, Q. R. S.; VIZEU, F. Construção e uso de conceitos em estudos organizacionais: por uma perspectiva social e histórica. Rev. Adm. Pública, v. 46, n. 2, p. 577-598, 2012.

MEADOWS, D. H.; RANDERS, J.; MEADOWS, D. Limites do crescimento: a atualização de 30 anos. Rio de Janeiro: Qualitymark, 2007.

NORMAN, W.; MACDONALD, C. Getting to the bottom of the "Triple Bottom Line". Business Ethics Quarterly, v. 14, n. 2, p. 243-262, 2004

O ESTADO DE S. PAULO. Para evitar um novo apagão. O Estado de S. Paulo, 23 abr. 2007, p. 3.

O GLOBO. Futuro em questão: nossa opinião. O Globo, 6 ago. 2007, p. 6. Disponível em: <http://acervo.oglobo.globo. com/?service=printPagina\&imagemPrint=http\%3A\%2F\%2Fduyt0k3aayxim.cloudfront. net\%2FPDFs_XMLs_artigos\%2Fo_globo>. Acesso em: 20 dez. 2014.

ORDOÑES, Ramona. Eletrobras investe R\$ 47,5 bi até 2014. O Globo, 22 dez. 2010, p. 37

ORLANDI, E. P. Texto e discurso. In: ORLANDI, E. P.; LAGAZZIRODRIGUES, S. (Org.). Introdução às ciências da linguagem: discurso e textualidade. 2. ed. Campinas, SP: Pontes, 2010.
ORLANDI, E. P. Análise de discurso: princípios e procedimentos. 11. ed. Campinas, SP: Pontes, 2013.

RATTNER, H. Desenvolvimento e emprego: a viabilidade de uma tecnologia intermediária. Revista de Administração de Empresas, v. 14, n. 3, p. 145-153, 1974.

RIBAS, G. B. Hidrelétrica: energia nova, não poluente e acessível. Gazeta do Povo, 4 nov. 2008. Disponível em: <http://www.gazetadopovo.com.br/opiniao/conteudo.phtml?id=824421>. Acesso em: 30 dez. 2014.

RICOEUR, P. Interpretação e ideologias. Rio de Janeiro: Francisco Alves, 1990

SACHS, W. Introduction. In: SACHS, W. (Org.). The development dictionary: a guide to knowledge as power. New York: Zed, 2010. p. xv-xx.

SCHUMACHER, E. F. O negócio é ser pequeno: um estudo de economia que leva em conta as pessoas. 4. ed. Rio de Janeiro: Zahar, 1983.

SEIFERT, R. E.; VIZEU, F. Crescimento organizacional: uma ideologia gerencial? Revista de Administração Contemporânea, v. 19, n. 1, p. 127-141, 2015a.

SEIFERT, R. E.; VIZEU, F. Tréplica: Davi e Golias - possibilidades de ruptura ao gigantismo em estudos organizacionais e de gestão. Revista de Administração Contemporânea, v. 19, n. 1, p. 160-168, 2015b.

SHAMIR, R. Mind the gap: commodifying corporate social responsibility. Symbolic Interaction, v. 28, n. 2, p. 229-253, 2005.

SILVA, S.; REIS, R.; AMANCIO, R. Paradigmas ambientais nos relatos de sustentabilidade de organizações do setor de energia elétrica. Revista de Administração Mackenzie, v. 12, n. 3, p. 146-176, 2011.

VIZEU, F.; MENEGHETTI, F. K.; SEIFERT, R. E. Por uma crítica ao conceito de desenvolvimento sustentável. Cad. EBAPE.BR, v. 10, n. 3, p. 569-583, 2012.

WANNER, T. The new 'passive revolution' of the green economy and growth discourse: maintaining the 'sustainable development' of neoliberal capitalism. New Political Economy, v. 20, n. 1, p. 21-41, 2015.

Luiz Gustavo Alves de Lara

Doutorando em Administração pelo PMDA/UP; Professor Colaborador no DEADM/UNICENTRO, Irati, PR, Brasil. E-mail: luizusf@hotmail.com

Samir Adamoglu de Oliveira

Doutor em Administração pelo PPGADM-UFPR; Professor adjunto no DADM-UFPB, João Pessoa, PB, Brasil; Professor colaborador no PMDA/UP, Curitiba, PR, Brasil; Pesquisador associado do IBEPES, Curitiba- PR, Brasil. E-mail: samiroliveira09@hotmail.com 